\title{
Detergent-resistant microdomains mediate activation of host cell signaling in response to attaching-effacing bacteria
}

\author{
Grace Shen-Tu' ${ }^{1,2}$, David B Schauer, ${ }^{3,4}$ Nicola L Jones ${ }^{1,4,5}$ and Philip M Sherman ${ }^{1,2,4,6}$
}

Enterohemorrhagic Escherichia coli (EHEC) O157:H7 causes outbreaks of bloody diarrhea and the hemolytic-uremic syndrome. EHEC intimately adheres to epithelial cells, effaces microvilli and induces attaching-effacing (AE) lesions. Detergent-resistant microdomains (lipid rafts) serve as membrane platforms for the recruitment of signaling complexes to mediate host responses to infection. The aim of this study was to define the role of lipid rafts in activating signal transduction pathways in response to AE bacterial pathogens. Epithelial cell monolayers were infected with EHEC (MOI 100:1, $3 \mathrm{~h}, 37^{\circ} \mathrm{C}$ ) and lipid rafts isolated by buoyant density ultracentrifugation. Phosphoinositide 3-kinase (PI3K) localization to lipid rafts was confirmed using PI3K and anti-caveolin-1 antibodies. Mice with cholesterol storage disease Niemann-Pick, type $C$ were used as in vivo models to confirm the role of lipid rafts in mediating signaling response to $A E$ organisms. In contrast to uninfected cells, PI3K was recruited to lipid rafts in response to EHEC infection. Metabolically active bacteria and cells with intact cholesterol-rich microdomains were necessary for the recruitment of second messengers to lipid rafts. Recruitment of PI3K to lipid rafts was independent of the intimin (eaeA) gene, type III secretion system, and production of Shiga-like toxins. Colonization of $\mathrm{NPC}^{-/-}$colonic mucosa by Citrobacter rodentium and $\mathrm{AE}$ lesion formation were both delayed, compared with wild-type mice infected with the murine-specific AE bacterial pathogen. C. rodentium-infected $\mathrm{NPC}^{-1-}$ mice had reduced colonic epithelial hyperplasia $(64 \pm 8.251 \mathrm{vs} 112 \pm 2.958 \mu \mathrm{m}$; $P<0.05)$ and decreased secretion of IFN- $\gamma(17.6 \pm 17.6$ vs $71 \pm 26.3 \mathrm{pg} / \mathrm{ml}, P<0.001)$. Lipid rafts mediate host cell signal transduction responses to $A E$ bacterial infections both in vitro and in vivo. These findings advance the current understanding of microbial-eukaryotic cell interactions in response to enteric pathogens that hijack signaling responses mediated through lipid rafts.

Laboratory Investigation (2010) 90, 266-281; doi:10.1038/labinvest.2009.131; published online 7 December 2009

KEYWORDS: colonic epithelial cell hyperplasia; enterohemorrhagic Escherichia coli O157:H7; Citrobacter rodentium; lipid rafts; microbial-host interaction; phosphoinositide 3-kinase

Escherichia coli is a facultative Gram-negative bacterium normally present in commensal colonic microflora. However, some E. coli strains possess specific virulence factors enabling them to cause disease in mammalian hosts. ${ }^{1}$ Enterohemorrhagic Escherichia coli (EHEC) O157:H7 is responsible for outbreaks of diarrhea, hemorrhagic colitis and the hemolytic-uremic syndrome (HUS), which is the most common cause of acute renal failure in children. ${ }^{2}$ For instance, an E. coli O157:H7 outbreak in North America was reported in the fall of 2006 initiated from the ingestion of contaminated, prepackaged spinach. ${ }^{3}$

Several virulence factors are thought to mediate disease pathogenesis. EHEC produces a potent cytotoxin known as Vero (Shiga-like) toxin. ${ }^{4}$ Verotoxin is an $\mathrm{AB}_{5}$ subunit toxin that binds to globotriaosylceramides $\left(\mathrm{Gb}_{3}\right)$ that are localized in membrane lipid rafts of host cells, ${ }^{5}$ inactivates $28 \mathrm{~S}$ ribosomal RNA to disrupt protein synthesis, and promotes apoptosis, leading to epithelial cell death. ${ }^{6}$

\footnotetext{
${ }^{1}$ Research Institute, Hospital for Sick Children, University of Toronto, Toronto, ON, Canada; ${ }^{2}$ Institute of Medical Science, University of Toronto, Toronto, ON, Canada; ${ }^{3}$ Division of Comparative Medicine, Department of Biological Engineering, Massachusetts Institute of Technology, Cambridge, MA, USA; ${ }^{4}$ Department of Paediatrics, University of Toronto, Toronto, ON, Canada; ${ }^{5}$ Department of Physiology, University of Toronto, Toronto, ON, Canada and ${ }^{6}$ Laboratory Medicine \& Pathobiology, University of Toronto, Toronto, ON, Canada

Correspondence: Dr PM Sherman, MD, FRCPC, Department of Paediatrics, Hospital for Sick Children, Room 8409, 555 University Avenue, Toronto, Ontario, Canada M5G 1X8.

E-mail: philip.sherman@sickkids.ca

"Deceased.
}

Received 18 April 2009; revised 27 October 2009; accepted 29 October 2009 
EHEC O157:H7 infection is also characterized by intimate bacterial attachment to epithelial cells mediated through a variety of adherence factors. ${ }^{7}$ E. coli-secreted proteins, encoded on a 35-kilobase pathogenicity island referred to as the locus of enterocyte effacement (LEE), are injected into the cytosol of infected cells through a type III secretion systemencoded molecular syringe. ${ }^{8}$ The translocating intimin receptor (Tir), also known as EspE, functions as a receptor for the eae gene-encoded bacterial outer membrane protein, intimin. ${ }^{9}$ Tir-intimin interactions give rise to intimate attachment of EHEC O157:H7 to eukaryotic cells and the recruitment of host actin cytoskeleton elements, which form dense adhesion pedestals and the effacement of intestinal brush-border microvilli, collectively known as the attachingeffacing (AE) lesion. ${ }^{1}$

Citrobacter rodentium is a naturally occurring mouse-specific noninvasive bacterial pathogen that is genetically related to EHEC, because it also uses AE lesion formation as a mechanism of infection and colonization of the colon. Genes encoding the ability of both $C$. rodentium and EHEC to induce $\mathrm{AE}$ lesions are located on the LEE pathogenicity island. C. rodentium infection of mice causes colonic epithelial hyperplasia that resolves spontaneously by postinfection day $28 .^{10}$

The effector protein Tir is inserted into cholesterol- and sphingolipid-enriched microdomains in the eukaryotic cell plasma membrane bilayer, referred to as lipid rafts. ${ }^{11,12}$ Cholesterol is an important component of eukaryotic cellular membranes, which is known to dynamically associate with sphingolipids to form heterogeneous microdomains (lipid rafts). ${ }^{13}$ These cholesterol-enriched microdomains serve as platforms for the recruitment of cell signaling complexes to a microenvironment in which they are sheltered from nonraft enzymes that can interfere with signaling processes. ${ }^{13,14}$ Lipid rafts contribute to a variety of functions in eukaryotic cells, including cell signaling, trafficking, and protein sorting. ${ }^{15,16}$
The aim of this study was to determine whether AE bacterial infections promote the recruitment of phosphoinositide 3-kinase (PI3K) to lipid rafts and determine the role of these microdomains in disease pathogenesis.

\section{MATERIALS AND METHODS Tissue Culture Cell Lines}

The HEp-2 human laryngeal epithelial cell line (CCL23; American Type Culture Collection, Manassas, VA, USA) and Intestine 407 embryonic intestinal cells (CCL-6; ATCC) were used as model systems in vitro. HEp-2 cells were cultured at $37^{\circ} \mathrm{C}$ in $5 \% \mathrm{CO}_{2}$ in minimal essential medium (MEM) supplemented with $10 \%$ fetal bovine serum, $1 \%$ sodium bicarbonate, $1 \%$ Fungizone, and $1 \%$ penicillin-streptomycin. Intestine 407 cells were cultured in MEM supplemented with $10 \%$ fetal bovine serum and 2\% penicillin-streptomycin (all media and supplemental reagents from Life Technologies, Grand Island, NY, USA).

\section{Bacterial Strains and Growth Conditions}

The bacterial strains used in this study are shown in Table 1 . EHEC O157:H7, strain CL56 and E. coli O113:H21, strain CL15 were stored at $-80^{\circ} \mathrm{C}$ and regrown on $5 \%$ sheep blood agar plates at $4^{\circ} \mathrm{C}$. Colonies were transferred from plates into Penassay broth and incubated at $37^{\circ} \mathrm{C}$ for $18 \mathrm{~h}$ and then regrown for $3 \mathrm{~h}$ in an antibiotic-free tissue culture medium at $37^{\circ} \mathrm{C}$ for mid-log phase. Heat-killed bacteria were prepared by boiling mid-log phase bacteria at $100^{\circ} \mathrm{C}$ for $30 \mathrm{~min}$. Formalin-fixed bacteria were washed with phosphate-buffered saline (PBS) and treated with formaldehyde (12\%) for $6-8 \mathrm{~h}$ at $4^{\circ} \mathrm{C}$.

Before infection of tissue culture cells, bacteria were washed with PBS and resuspended in antibiotic-free MEM. For chloramphenicol treatment, mid-log phase bacteria were pelleted and resuspended in chloramphenicol $(100 \mu \mathrm{g} / \mathrm{ml})$ for $6-8 \mathrm{~h}$ at $4^{\circ} \mathrm{C} .{ }^{17}$ Bacteria were added to epithelial cells grown in $10 \mathrm{~cm}$ diameter tissue culture dishes (Starstedt, Montreal,

Table 1 Bacterial strains and treatments used in the in vitro studies

\begin{tabular}{|c|c|c|c|c|}
\hline Escherichia coli strains & Treatment & Description & Source & Reference \\
\hline \multirow[t]{3}{*}{ CL56 (EHEC O157:H7) } & Boil at $100^{\circ} \mathrm{C}$ for $30 \mathrm{~min}$ & Non-viable bacteria with disrupted structure & HC, HUS & 2,17 \\
\hline & Chloramphenicol & Stop the bacterial protein synthesis & & \\
\hline & Formaldehyde & Kill the bacteria but keeping the structure intact & & \\
\hline CL15 (O113:H21) & - & Without the LEE pathogenicity island & HC, HUS & 38 \\
\hline $86-24$ & - & Wild-type EHEC & HC, HUS & 17 \\
\hline CVD451 & - & Type III secretion-deficient mutant of parental strain 86-24 & Lab & 17 \\
\hline $85-289$ & - & Wild-type EHEC & HC, HUS & 17 \\
\hline $85-170$ & - & Stx1 and Stx2 negative mutants of parental strain $85-289$ & Lab & 17 \\
\hline
\end{tabular}

Abbreviations: HC, hemorrhagic colitis; HUS, hemolytic uremic syndrome.

The various strains of $E$. coli and related mutants were grown overnight on sheep blood agar from frozen stocks in $37^{\circ} \mathrm{C}$ and subsequently grown in Penassay broth overnight. The overnight growth in broth was used to infect model cell lines to delineate microbial-host cell interaction through signaling cross-talk. 
Que., Canada), at a multiplicity of infection of 100 bacteria to one eukaryotic cell, for $1 \mathrm{~h}$ at $37^{\circ} \mathrm{C}$ in antibiotic-free MEM. Uninfected cells were used as a negative control. After $1 \mathrm{~h}$ of infection, cells were washed with PBS ( $\mathrm{pH}$ 7.0) to remove nonadherent bacteria.

\section{Cultured Supernatant and Conditioned Medium Preparation}

To collect bacterial culture supernatants, $10 \mathrm{ml}$ of EHEC O157:H7 grown in Penassay broth was centrifuged at 3000 r.p.m. for $15 \mathrm{~min}$ and the supernatant was filtered using a $0.45 \mu \mathrm{m}$ filter into a new tube for storage at $-20^{\circ} \mathrm{C}$ until use. To collect conditioned medium, EHEC O157:H7 strain CL-56 grown overnight in $10 \mathrm{ml}$ Penassay broth $\left(37^{\circ} \mathrm{C}\right)$ was used to infect monolayers of HEp-2 cells (MOI 100:1). After $1 \mathrm{~h}$, the medium was centrifuged ( 3000 r.p.m., $15 \mathrm{~min}$ ), and $30 \mathrm{ml}$ of conditioned medium was pooled together and concentrated using a $3 \mathrm{kDa}$ Amicon Ultrafilter (Millipore). Unfiltered conditioned medium was collected using centrifugation and $100 \mu \mathrm{g} / \mathrm{ml}$ of chloramphenicol was added to halt bacterial protein synthesis.

C. rodentium, strain DBS100 (ATCC 51459) was stored in Luria Bertani (LB) broth with $50 \%$ glycerol at $-80^{\circ} \mathrm{C}$. Bacteria were grown from frozen stocks on $\mathrm{LB}$ agar plates at $37^{\circ} \mathrm{C}$ and stored at $4^{\circ} \mathrm{C}$ for no more than 2 weeks. Bacteria were inoculated into $10 \mathrm{ml} \mathrm{LB}$ broth and grown at $37^{\circ} \mathrm{C}$ overnight. Before infection of mice, overnight cultures were centrifuged at 3000 r.p.m. for $10 \mathrm{~min}$ and resuspended in $2.5 \mathrm{ml}$ of LB broth to obtain a concentration of $10^{10}$ bacteria per $\mathrm{ml}$.

\section{Whole-Cell Protein Extraction}

HEp-2 cells were infected either with Escherichia coli O157H7 or with $C$. rodentium for 1,3 , and $6 \mathrm{~h}$. Cells were washed thrice with ice-cold PBS ( $\mathrm{pH}$ 7.0) and whole-cell protein extracts were collected for storage at $-80^{\circ} \mathrm{C}$, as previously described. ${ }^{18}$

\section{Depletion of Cholesterol using Methyl- $\beta$-Cyclodextrin (MBCD)}

HEp-2 cells were treated with M $\beta C D$ (Sigma Chemical, St Louis, MO, USA) (1-10 mM) to disrupt cholesterol-enriched microdomains by chelating plasma membrane cholesterol. ${ }^{19}$ Before bacterial infection, epithelial cells were incubated with $\mathrm{M} \beta \mathrm{CD}(10 \mathrm{mM})$ in antibiotic-free MEM for $1 \mathrm{~h}$ at $37^{\circ} \mathrm{C}$. The medium was aspirated off cell monolayers and washed with PBS before bacterial infection. ${ }^{20}$

\section{Treatment with Pharmacological Inhibitors}

Tissue culture cells were preincubated with either the phosphoinositide-3 kinase inhibitor LY294002 (100 $\mu$ M; Sigma Chemical) or with an equal concentration of the inactive analog LY303511 for $1 \mathrm{~h}$ at $37^{\circ} \mathrm{C}^{21}$ After removal of the inhibitor, cells were rinsed with PBS and infected with bacteria for $1 \mathrm{~h}$ at $37^{\circ} \mathrm{C}$.

\section{Isolation of Detergent-Resistant Membranes}

Infected epithelial cells were scraped and pelleted in $4 \mathrm{ml}$ of sterile PBS in $15 \mathrm{ml}$ conical tubes. Cells were then lysed with $0.8 \mathrm{ml}$ TN buffer $(25 \mathrm{mM}$ tris- $\mathrm{HCl} \mathrm{pH} 7.5,150 \mathrm{mM} \mathrm{NaCl}$, $1 \mathrm{mM}$ DTT, $10 \%$ sucrose, $1 \%$ Triton X-100, leupeptin, $2 \mu \mathrm{g} / \mathrm{ml}$ pepstatin A, $10 \mu \mathrm{g} / \mathrm{ml}$ aprotonin, $0.5 \mathrm{mM}$ PMSF, $1 \mathrm{mM} \mathrm{Na} \mathrm{VO}_{4}$ ) for $30 \mathrm{~min}$ on ice. The samples were then mixed with $1.7 \mathrm{ml}$ of Optiprep (Axis-Shield PoC AS, Oslo, Norway) and transferred into SW41 centrifuge tubes (Beckman Instruments, Palo Alto, CA, USA). Optiprep (60\%) was diluted with TN buffer to produce 35 and $5 \%$ solutions (adapted from references ${ }^{22}$ and $^{23}$ ), which were then layered on top of samples and centrifuged at $160000 \times g$ for $20 \mathrm{~h}$ at $4^{\circ} \mathrm{C}$. Eight $1.5 \mathrm{ml}$ fractions were then collected from top to bottom of the gradient generated by ultracentrifugation. ${ }^{24}$

\section{Immunoblotting}

Aliquots $(10 \mu \mathrm{l})$ of each fraction were analyzed for PI3K and caveolin-1. Proteins were separated by precast $10 \%$ Tris- $\mathrm{HCl}$ (Biorad) sodium dodecyl sulfate polyacrylamide gel electrophoresis (SDS-PAGE) with a protein ladder standard (BioRad, broad molecular range ladder) at $120 \mathrm{~V}$ for $1-1.25 \mathrm{~h}$ at room temperature. After electrophoresis, proteins were transferred onto nitrocellulose membranes (Pall Corporation, Pensacola, FL, USA) at $100 \mathrm{~V}$ for $1.5 \mathrm{~h}$ at $4^{\circ} \mathrm{C}$ and incubated in Odyssey blocking buffer (LI-COR Biosciences, Lincoln, NE, USA) for $0.5-1 \mathrm{~h}$ at $20^{\circ} \mathrm{C}$. Blocking buffer was then decanted off and membranes were probed with anti-caveolin1 as a lipid raft marker protein (Santa Cruz Biotechnology, CA, USA; 1:1000) and with primary antibodies against PI3K p85 (Upstate Biotechnology, Lake Placid, NY, USA; 1:1000) overnight at $4^{\circ} \mathrm{C}$ on a shaker. Whole-cell extracts were probed with native- and phospho-Akt antibody (Cell Signaling, Beverly, MA, USA; 1:1000 dilution). After washing the membrane four times with PBS and $0.1 \%$ Tween ( 5 min per wash), IRDye 800 goat anti-rabbit immunoglobulin G (IgG) secondary antibody (Rockland Immunochemicals, Gilbertsville, PA, USA; 1:20000) was added and incubated for $1 \mathrm{~h}$ at room temperature on a shaker. The blots were then washed four times with PBS and $0.1 \%$ Tween and once with PBS alone. The membrane was then scanned using the Odyssey system (LI-COR Biosciences) with the $800 \mathrm{~nm}$ channel. The integrative intensity of the detected bands was obtained using software provided with the infrared imaging system (LI-COR Biosciences). Western analysis was performed on collected whole-cell lysates probed with both Akts (Cell Signaling, Denvor, MA, USA; 1:1000 dilution).

\section{Immunostaining}

HEp-2 cells were grown to subconfluency and treated with $\mathrm{M} \beta \mathrm{CD}$ ( $10 \mathrm{mM}$; Sigma Chemical) for $1 \mathrm{~h}$ at $37^{\circ} \mathrm{C}$. To add cholesterol back into cholesterol-depleted cells, $200 \mu \mathrm{g} / \mathrm{ml}$ of soluble cholesterol (Sigma) in an antibiotic-free medium was added to cells for $45 \mathrm{~min}$ at $37^{\circ} \mathrm{C}$. After depletion-repletion of cholesterol, cells were washed with PBS, fixed in 3.7\% 
paraformaldehyde, and permeabilized with $0.1 \%$ Triton X100. Lipid rafts were visualized using Alexa Fluor 594-labeled cholera toxin subunit B (Invitrogen, Carlsbad, CA, USA). ${ }^{25}$

\section{Animals}

$\mathrm{BALB} / \mathrm{c}$ mice $(n=5$ for 6 days uninfected and C. rodentium infected; $n=5$ for 12 days uninfected and C. rodentium infected) and homozygous BALB/cNctr-npcl ${ }^{\mathrm{mlN} / \mathrm{mlN}}$ $\left(\mathrm{Npcl}^{--}\right)$mice ( $n=4$ for 6 days uninfected and C. rodentium infected; $n=4$ for 12 days uninfected and $C$. rodentium infected) with Niemann-Pick type C disease were obtained from Jackson Laboratory (Bar Harbor, ME, USA) at 4-5 weeks of age, before the onset of a progressive neurological disorder. ${ }^{26}$ Animals were housed in microisolate cages in a containment unit and were allowed free access to water and chow. All animal experiments were carried out after review and approval by the Laboratory Animal Services, Hospital for Sick Children, Toronto, ON, Canada.

\section{Infection of Mice with $C$. rodentium}

Mice were inoculated orogastrically with either $10^{9} \mathrm{C}$. rodentium in $100 \mu \mathrm{LB}$ broth, or sham infected with an equal volume of LB broth alone, and then followed up for 6-12 days. ${ }^{10}$ Mice were monitored for bacterial shedding using rectal swabs streaked onto MacConkey lactose agar plates. ${ }^{27}$

\section{Tissue Collection}

At necropsy, spleens and colonic sections were harvested for further experimental analyses. Spleens were placed into $4 \mathrm{ml}$ of RPMI tissue culture medium and kept on ice. Segments ( $\sim 5 \mathrm{~mm}$ in length) of distal colon were placed into Universal fixative (4\% paraformaldehyde, $1 \%$ glutaraldehyde in $0.1 \mathrm{M}$ phosphate buffer) for further processing by electron microscopy. ${ }^{28}$ Segments from the remainder of the distal colon were placed in $10 \%$ neutral-buffered formalin and processed for histological assessment. In some experimental groups, mice were injected intraperitoneally with a $10 \mathrm{mg} / \mathrm{ml} 5$-bromo- 2'-deoxyuridine (BrdU; Sigma) solution in PBS at a concentration of $5 \mu \mathrm{l} / \mathrm{g} 1 \mathrm{~h}$ before being killed. Mice injected with BrdU were not used to prepare splenocytes.

\section{Histology and Immunohistochemistry}

Formalin-fixed tissues were embedded in paraffin, sectioned at 5-7 $\mu \mathrm{m}$, and mounted onto positively charged microscope slides for further processing. For histology, slides were rinsed in distilled water and stained with Mayer's hematoxylin for $15 \mathrm{~min}$. Excess stain was removed by rinsing in water and sections were fixed by rinsing five times in ammonia water. Slides were then rinsed in 95\% ethanol and counterstained in eosin for $3 \mathrm{~min}$.

To detect C. rodentium bound to intestinal mucosal surfaces using immunohistochemistry, mounted tissue sections were baked overnight at $60^{\circ} \mathrm{C}$, dewaxed in xylene, and hydrated to distilled water through decreasing concentrations of ethanol. The immunohistochemical procedure was per- formed on an auto-immunostainer (NEXES, Vetana Medical Systems, Tuscon, AZ, USA). Rabbit polyclonal anti-C. rodentium diluted 1:400, as well as secondary antibody staining with biotinylated anti-rabbit IgG (Vector Laboratiories, Burlingame, CA, USA) at a dilution of 1:100, was detected using a DAB (3-3'-diaminobenzidine) detection system (Ventana Medical Systems, Tuscon, AZ, USA). Slides were then counterstained with hematoxylin to provide nuclear detail.

To detect apoptotic cells, TUNEL assay for in situ end labeling was performed and adapted to an automated immuno/in situ hybridization instrument (Discovery, Ventana). Before staining, colonic sections were deparaffinized, as above, and blocked for endogenous peroxidase by Protease I (Ventana Medical Systems) digestion for $12 \mathrm{~min}$. Slides were then incubated with recombinant terminal deoxynucleotidyl transferase (GIBCO BRL, Life Technologies, Grand Island, NY, USA) and biotin 16-dUTP (Roche Diagnostics Corporation, Indianapolis, IN, USA) to label the nuclei of cells undergoing programmed cell death. ${ }^{29}$ Colorimetric visualization, using avidin-HRP and DAB, was performed as described above.

To detect proliferating cells within colonic crypts, colonic sections from mice injected intraperitoneally with BrdU before being killed were dewaxed and hydrated, as detailed above. Slides were then treated with pepsin digestion, acidified in $4 \mathrm{~N} \mathrm{HCl}$ to denature DNA, and blocked for endogenous peroxidase. Immunohistochemical staining with a mouse anti-BrdU antibody (Dako, Carpinteria, CA, USA) was performed on an auto-immunostainer (Discovery, Ventana Medical Systems) at a dilution of 1:50 using the ARK kit (Dako) to prevent mouse-on-mouse cross reactivity. Detection and visualization used a peroxidase-conjugated streptavidin secondary reagent (Dako) and a DAB chromogen substrate.

Histology and immunohistochemistry slides were viewed using a light-field microscope (Leica DM 4600B, Leica Microsystems, Richmond Hill, ON, Canada). Photomicrographs were captured using a digital camera (Leica DC 500) and analyzed using integrated software (Leica IM500 Image Manager).

\section{Transmission Electron Microscopy}

Distal colonic segments fixed in Universal fixative for $24 \mathrm{~h}$ were postfixed in $2 \%$ aqueous osmium tetroxide for $1 \mathrm{~h}$ at $20^{\circ} \mathrm{C}$. Dehydration was performed in graded acetone, followed by embedding in epoxy resin. Osmium postfixation, dehydration, and embedding were conducted in a Pelco Biowave microwave oven (Pelco International, Redding, CA, USA). One-micrometer-thick sections were stained with toluidine blue and ultrathin sections were stained with uranyl acetate and lead citrate. Electron microscopy examination was performed using a transmission electron microscope (JEM 1230, Joel USA Corp., Peabody, MA, USA). 


\section{Cytokine Profiles of Splenocytes}

The production of IFN- $\gamma$ and IL-10 from isolated splenocytes was performed, as described previously. ${ }^{27,30}$ Briefly, spleens were mashed through sterile filter screens in RPMI medium to obtain single-cell suspensions. Cells were incubated in red cell lysis buffer for $3 \mathrm{~min}$ and washed three times. The pellet was layered with $5 \mathrm{ml}$ of lympholyte-M (Cedarlanes Laboratories, Hornby, ON, Canada) and spun at 1000 r.p.m. for $10 \mathrm{~min}$. Isolated cells were washed three times and resuspended in RPMI medium containing 10\% fetal calf serum. Splenocytes were enumerated and equal numbers of cells were incubated with sterile $C$. rodentium whole-cell sonicate for $72 \mathrm{~h}$ at $37^{\circ} \mathrm{C}$. IFN- $\gamma$ and IL-10 cytokine levels were then measured using commercially available immunoassay kits (Medicorp, Montreal, Que., Canada), according to the manufacturer's instructions.

\section{Data Analyses}

Results are reported as means \pm standard errors of the mean (s.e.m.). To test for the significance between two groups, twotailed Student's $t$-test was used, with $P<0.05$ considered as statistically significant. One-way analysis of variance (ANOVA) was used for data derived from more than two study groups. ${ }^{31}$

\section{RESULTS}

\section{PI3K is Recruited to Lipid Rafts in Response to} Enterohemorrhagic $E$. coli Infection

After E. coli O157:H7 infection of HEp-2 cells, PI3K was recruited to the sucrose fraction containing caveolin-1, which was used as a lipid raft marker protein ${ }^{18}$ (Figure 1a). There was a significant increase in the amount of PI3K present in the lower density fraction of EHEC-infected cells, indicating that E. coli O157:H7 induced the translocation of PI3K to lipid rafts. Protein recruitment to lipid rafts was not observed when tissue culture cells were infected with heat-killed bacteria (Figure 1a), showing that recruitment of PI3K is triggered by exposure of epithelial cells to live organisms and not to bacterial surface-derived structural constituents. The increase in PI3K recruitment to lipid rafts in EHEC-infected cells was quantified by using densitometry to determine integrated intensity values (Figure $1 \mathrm{~b} ; n=5, P<0.05$ ). Chloramphenicol-treated bacteria also markedly reduced the recruitment of PI3K to lipid rafts (Figure 1c), indicating that activation of these signal transduction cascades is caused by newly synthesized bacterial proteins. ${ }^{32}$ EHEC O157:H7 infection of Intestine 407 cells also induced activation and translocation of PI3K (Figure 1d).

\section{PI3K Recruitment to Lipid Rafts is Independent of Known EHEC Virulence Factors}

Similar to observations in EHEC O157:H7-infected cells, an increase in PI3K level in caveolin-1-enriched fraction 3 was observed in response to infection with the eae-negative E. coli, strain CL15 (VTEC O113:H21), indicating that recruitment to lipid rafts in response to EHEC infection (Figure 1a) is independent of the AE (eae) gene, because strain CL15 does not contain the LEE pathogenicity island required to cause AE lesions. ${ }^{33}$ Infection of HEp-2 cells with E. coli, strain CVD451, a type III secretion-deficient mutant, ${ }^{17}$ also resulted in increased recruitment of PI3K to lipid rafts (Figure 2a). Similarly, infection with E. coli, strain 85-170, an Stx-1 and Stx-2 negative mutant, ${ }^{17}$ also showed the recruitment of host signaling molecules to lipid rafts (Figure 2a). Taken together, these findings indicate that recruitment of signal transduction molecules to lipid rafts is independent of the bacterial type III secretion system and the production of Shiga-like toxins 1 and 2.

\section{Recruitment of PI3K to Lipid Rafts is Blocked by a Specific PI3K Inhibitor}

Recruitment of PI3K in response to EHEC O157:H7 infection was reduced in cells pretreated with the PI3K inhibitor, LY294002 $(100 \mu \mathrm{M})$, by $40 \%$ (relative to EHEC-infected alone), but not when an equal concentration of an inactive analog (LY303511) was used (integrated intensity readings of the PI3K band in immunoblots, relative to caveolin-1, were 0.805 for LY294002-treated cells, 1.229 for LY303511-treated epithilia and 1.332 for EHEC-infected cells) (Figure 2b). DMSO alone, tested as a vehicle control, did not result in a reduction in PI3K recruitment to lipid rafts (data not shown). These findings support the hypothesis that activated PI3K is recruited to lipid rafts in response to EHEC infection. ${ }^{34}$

\section{M/CD Blocks PI3K Recruitment to Lipid Rafts in Response to EHEC Infection}

To confirm that EHEC O157:H7-induced translocation of host proteins to lipid rafts was dependent on intact lipid raft microdomains, pretreatment of cells with $\mathrm{M} \beta \mathrm{CD}(10 \mathrm{mM})$ was used to deplete cholesterol and thereby disrupt lipid rafts. ${ }^{20}$ Cells subjected to $\mathrm{M} \beta \mathrm{CD}$ pretreatment failed to recruit PI3K to lipid rafts in response to EHEC O157:H7 (Figure $3 \mathrm{~b}$ ). To verify that $\mathrm{M} \beta \mathrm{CD}$ induced disruption of lipid rafts, cholera toxin B subunit staining was performed. ${ }^{25}$ HEp-2 cells treated with $M \beta C D$ lacked visible choleragen $B$ subunit staining around cells (Figure $3 \mathrm{~h}$ ), compared with untreated cells (Figure $3 \mathrm{f}$ ). When $\mathrm{M} \beta \mathrm{CD}$-treated cells were rescued with soluble cholesterol, cholera toxin labeling again showed the presence of lipid rafts in the plasma membrane (Figure 3j).

\section{Culture Supernatant and Conditioned Medium Cannot Induce the Recruitment of PI3K to Lipid Rafts}

To determine whether bacterial-secreted factors were able to elicit EHEC-induced recruitment of PI3K to lipid microdomains, culture supernatants and conditioned media were collected. Cells treated with culture supernatant and conditioned medium (either filtered or nonfiltered) did not result in the recruitment of PI3K to lipid rafts (Figure $3 \mathrm{a}$ and $\mathrm{b}$ ). 
a



C

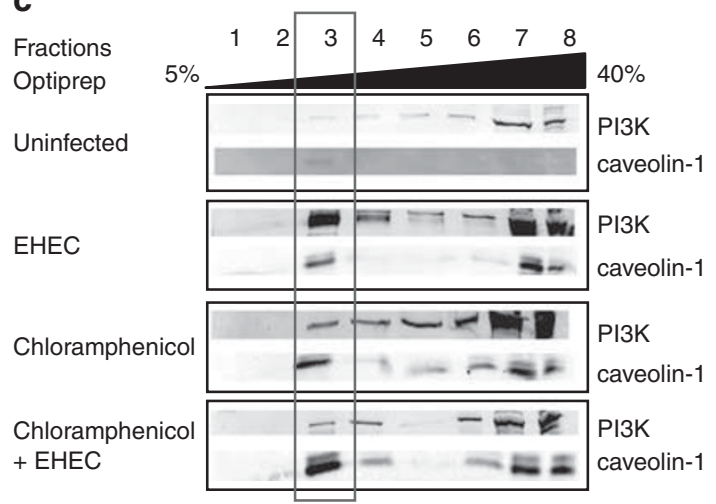

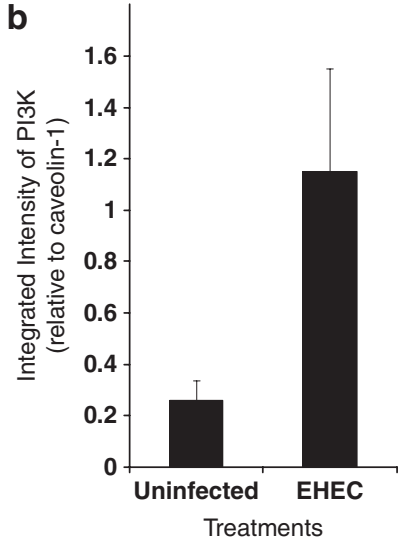

d

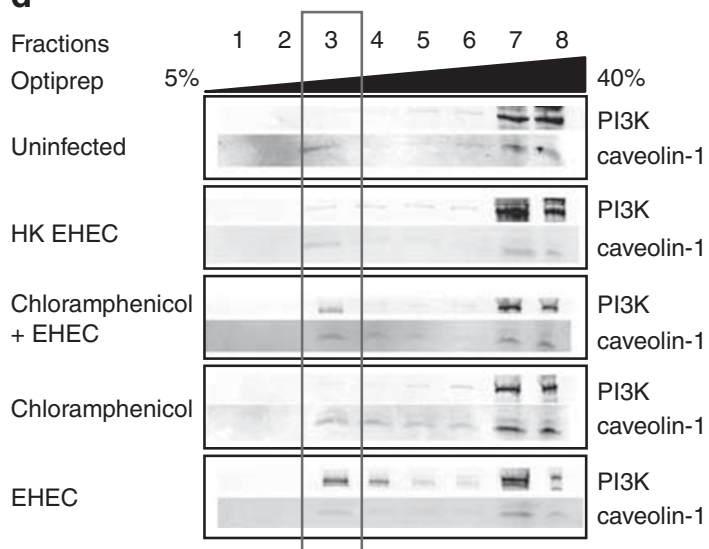

Figure 1 Phosphoinositide 3-kinase (PI3K) is recruited to lipid rafts in response to enterohemorrhagic Escherichia coli O157:H7 infection, and newly synthesized bacterial proteins are required for PI3K recruitment to lipid rafts. Western blots of PI3K from ultracentrifugation fractions of whole-cell (HEp-2) extracts. The presence of PI3K in the caveolin-1-containing fraction indicates that it is recruited to lipid rafts in response to bacterial infection. The presence of PI3K in fraction 3 of VTEC 0113:H21-infected cells indicate that recruitment is independent of the eae gene. The lack of PI3K in fraction 3 of uninfected and boiled EHEC-infected cells shows that recruitment is induced by live bacteria (a). Recruitment was quantified using densitometry and was expressed graphically $(n=5, P<0.05)$ (b). PI3K was not recruited in host cells infected with chloramphenicol-treated EHEC O157:H7, indicating that metabolically active bacteria are required for recruitment of host signaling proteins (c). EHEC-infected Intestine 407 cells also induced translocation of PI3K to lipid rafts (d).

\section{EHEC does not Activate the PI3K/Akt Pathway During Infection}

To investigate downstream signals activated in response to EHEC-mediated PI3K recruitment to lipid rafts, whole-cell protein extracts were taken $5 \mathrm{~min}$ to $1 \mathrm{~h}$ (Figure $3 \mathrm{~d}$ ), and at 3 and $6 \mathrm{~h}$ after infection (Figure $3 \mathrm{c}$ ). The amount of phophoAkt was determined by western blotting. Although PI3K was recruited to detergent-insoluble microdomains in response to EHEC infection, phosphorylation of Akt, which is a common downstream effector, ${ }^{34}$ was not detected.

\section{Delayed Colonization of NPC Colonic Mucosa by C. rodentium}

To extend these findings to an in vivo setting, wild-type $\mathrm{BALB} / \mathrm{c}$ and $\mathrm{NPC}^{-1-}$ mice were used. BALB/c and $\mathrm{NPC}^{-1-}$ mice were infected orogastrically with the murine-specific $\mathrm{AE}$ bacterium, C. rodentium. ${ }^{35}$ In all mice, C. rodentium was recovered by rectal swabbing starting at day 3 after orogastric challenge until the end of the infection protocol, indicating that the organism was able to successfully colonize and infect both wild-type and $\mathrm{NPC}^{-/-}$mice. Six days after challenge, there was a homogeneous bacterial adherence pattern on the colonic mucosa in infected BALB/c mice (Figure 4b). By contrast, there was minimal $C$. rodentium adherence detected on the colonic surface of $\mathrm{NPC}^{-1-}$ mice at 6 days after infection (Figure 4e). Furthermore, a more homogeneous pattern of bacterial adhesion was detected in $\mathrm{NPC}^{-1-}$ mice at 12 days after infection (Figure 4f). At this time, adherent bacteria were largely cleared from the mucosa of wild-type, $C$. rodentium-infected mice.

\section{C. rodentium-Induced AE Lesions are Delayed in NPC ${ }^{-1-}$ Mice}

Segments of the distal colon were assessed by transmission electron microscopy for the presence of $\mathrm{AE}$ lesions, characteristic of adherent $C$. rodentium. ${ }^{10}$ In contrast to uninfected mice, which showed intact apical microvilli on columnar epithelia (Figure 5a), wild-type mice challenged 


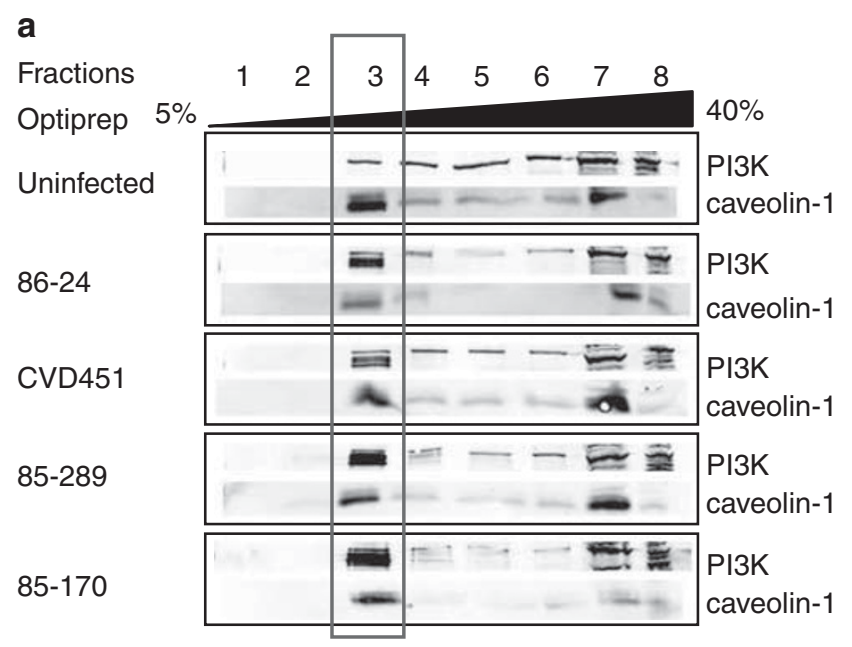

b

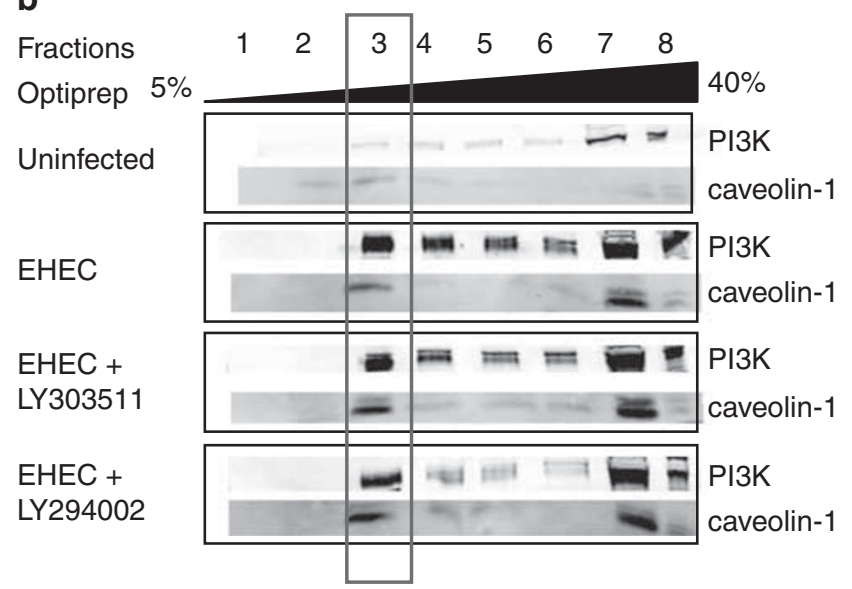

Figure 2 Activated phosphoinositide 3-kinase (PI3K) is recruited to lipid rafts in response to infection, independent of the type III secretion system and Shiga-like toxins 1 and 2. Western blots of PI3K from ultracentrifugation fractions of whole-cell (HEp-2) extracts. PI3K recruitment in EHEC mutant (CVD 451 and 85-170)-infected cells indicates that signaling is independent of the type III secretion system and Shiga-like toxins 1 and 2 (a). Cells treated with the PI3K inhibitor LY294002 before EHEC 0157:H7 infection had reduced amounts of PI3K recruited to lipid rafts, compared with the amount of PI3K recruited in cells treated with the inactive analog, LY303511, before EHEC infection (b).

with C. rodentium for 6 days had large numbers of intimately adherent bacteria with typical actin-enriched adhesion pedestals (Figure 5b), but by 12 days after inoculation, AE lesions were no longer observed (Figure $5 \mathrm{c}$ ). In contrast, $\mathrm{AE}$ lesions were not detected in $\mathrm{NPC}^{-l-}$ mice at 6 days after infection (Figure $5 \mathrm{~d}$ and e). Intimate bacterial adherence and adhesion pedestal formation was evident in $\mathrm{NPC}^{-1-}$ mice only after 12 days following $C$. rodentium infection (Figure 5f).

\section{C. rodentium-Infected NPC ${ }^{-1-}$ Mice Show Reduced Colonic Epithelial Cell Hyperplasia}

Compared with uninfected mice (Figure 6a), histological sections obtained from wild-type mice showed an increase in thickness of the colonic epithelium at both 6 (Figure 6b) and
12 days (Figure $6 \mathrm{c}$ ) after C. rodentium challenge. In contrast, $\mathrm{NPC}^{-1-}$ mice had a reduction in hyperplasia of the colonic mucosa in response to $C$. rodentium infection at 12 days (Figure 6d-g).

The reduction in mucosal thickness of $C$. rodentiuminfected $\mathrm{NPC}^{-1-}$ mice compared with $\mathrm{BALB} / \mathrm{c}$ mice could be because of either increased cell death or reduced cellular proliferation. Histological sections of $C$. rodentium-infected wild-type and $\mathrm{NPC}^{-1-}$ colonic tissue assessed by TUNEL assay showed no differences in surface epithelial cell apoptosis (data not shown). However, colonocyte proliferation, assessed through BrdU staining in infected wild-type mice, showed an increase in both the number of mitotic cells and the size of the proliferation zone at both 6 (Figure 7b) and 12 days (Figure 7c) after infection compared with uninfected mice (Figure 7a). Colonocyte proliferation was maximal at day 6 after infection in wild-type mice. In contrast to wildtype mice, $C$. rodentium infection of $\mathrm{NPC}^{-1-}$ mice resulted in only moderate increases in epithelial cell mitosis at both 6 and 12 days after infectious challenge, when maximal bacterial colonization was present (Figure $7 \mathrm{e}$ and $\mathrm{f}$, respectively). These changes were quantified as increases in the zone of proliferation - the maximal height of BrdU-labeled cells from the base of well-oriented crypts (Figure 7g).

\section{NPC $^{-1-}$ Mice Produce Reduced Levels of the Proinflammatory Cytokine IFN- $\gamma$ in Response to C. rodentium Infection}

Epithelial hyperplasia and colonic mucosal inflammation in C. rodentium infection is analogous to enteric immunopathological conditions in patients, such as chronic inflammatory bowel disease. ${ }^{10}$ Multiple proinflammatory cytokines are elicited in response to $C$. rodentium infection. ${ }^{36,37}$ Therefore, to assess the adaptive immune responses elicited, splenocytes were isolated from uninfected and C. rodentium-challenged $\mathrm{BALB} / \mathrm{c}$ and $\mathrm{NPC}^{-1-}$ mice. Isolated splenocytes were stimulated in vitro with $C$. rodentium sonicate and then IFN- $\gamma$ and IL-10 levels were measured as representative of Th1 and $\mathrm{T}_{\text {regulatory }}$ cytokine responses, respectively. ${ }^{27}$ As shown in Figure 8a, wild-type mice showed a proinflammatory, Th1-predominant cytokine response 12 days after $C$. rodentium exposure. By contrast, infected $\mathrm{NPC}^{-1-}$ mice had a reduced IFN- $\gamma$ response. This response may be regulated by an increased $\mathrm{T}_{\text {regulatory }}$ response, because higher levels of IL-10 were present in splenocytes derived from $\mathrm{NPC}^{-/-}$mice at both 6 and 12 days after infection, compared with wild-type mice challenged with $C$. rodentium (Figure 8b).

\section{DISCUSSION}

Multiple signaling molecules have a role in orchestrating host cell responses to EHEC infection, ${ }^{21}$ leading to the development of mucosal inflammation, ${ }^{38}$ cytoskeleton rearrangements, ${ }^{39}$ and disruption of intercellular tight junctions. ${ }^{40} \mathrm{PI} 3 \mathrm{~K}$, a lipid kinase, catalyzes the production of 
a

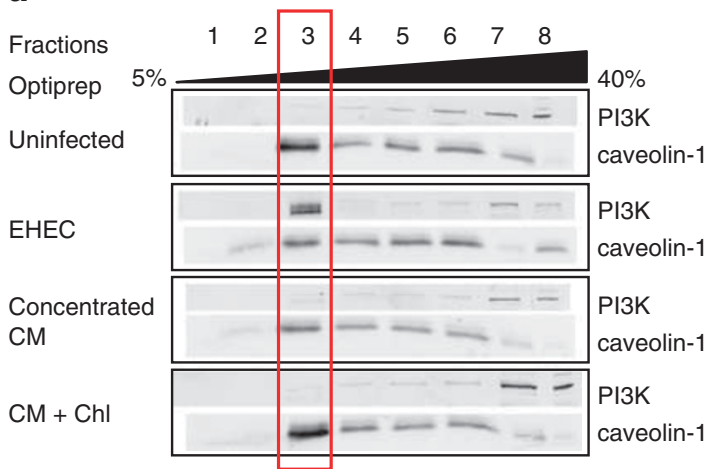

b

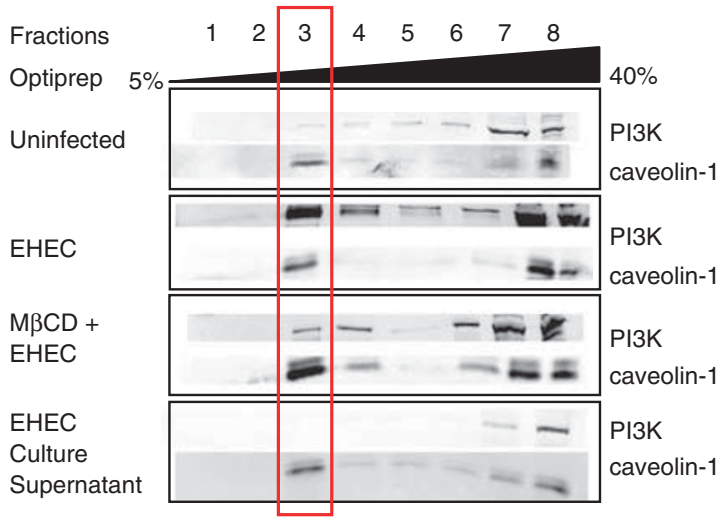

C
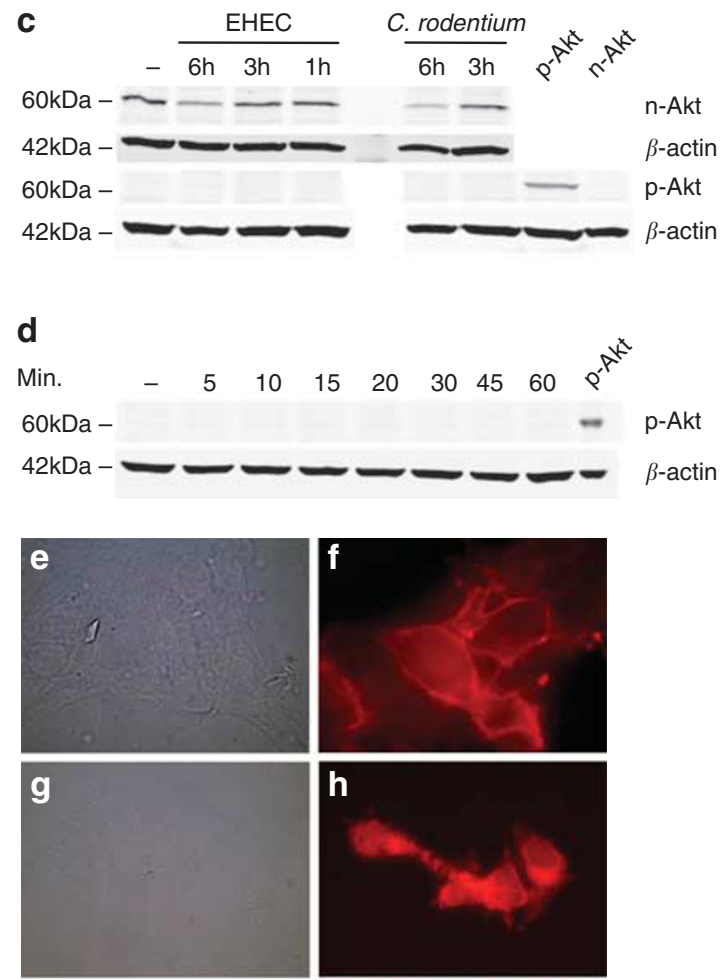

h
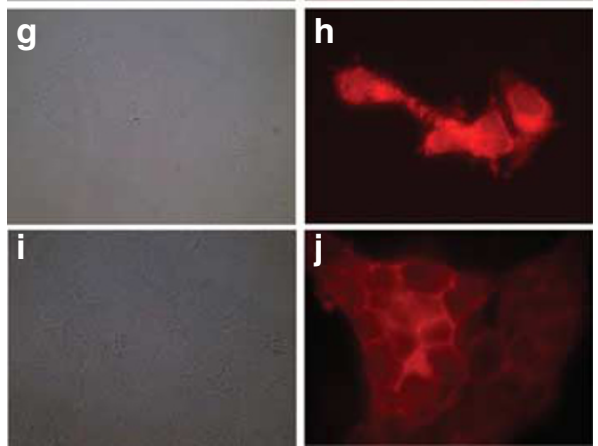

Figure 3 Intact lipid microdomains are required for EHEC-induced translocation of phosphoinositide 3-kinase (PI3K) to lipid rafts, whereas secreted bacterial factors are insufficient to induce this recruitment. Conditioned medium did not induce the recruitment of PI3K to lipid microdomains on host cell membranes (a). Disruption of lipid rafts by depleting cellular cholesterol using $\mathrm{M} \beta \mathrm{CD}(10 \mathrm{mM})$ leads to decreased recruitment of the host signaling protein, $\mathrm{PI3K}$, in response to EHEC O157:H7 infection. Culture supernatant alone was unable to induce recruitment of PI3K (b). Phosphorylation of the PI3K downstream effector Akt was not detected in response to EHEC and C. rodentium infections (c, d), suggesting an alternative activated pathway. Lipid raft disruption after cholesterol-depleting $\mathrm{M} \beta \mathrm{CD}$ treatment was visualized using Alexa fluor 594-labeled cholera toxin subunit $\mathrm{B}$ : untreated cells (e and $\mathbf{f}$ ), $\mathrm{M} \beta \mathrm{CD}$ treated cells $(\mathbf{g}, \mathbf{h})$, and $\mathrm{M} \beta \mathrm{CD}$-treated epithelia replenished with soluble cholesterol $(\mathbf{i}, \mathbf{j})$.

membrane-bound lipid second messengers after stimulation through tyrosine kinases, cytokine receptors, and integrin receptors. ${ }^{41}$ In response to pathogen infections, PI3K regulates cytoskeleton rearrangements following both bacterial adhesion $^{42}$ and invasion ${ }^{43}$ of other bacterial pathogens. However, the mechanisms by which EHEC modulates host signal transduction pathways are still largely unknown.

Akt, also known as $\mathrm{PKB}$, is a key regulator of host cell survival by inhibiting apoptosis, control of the cell cycle and various proinflammatory responses, including the activation of the transcription factor NF $\kappa \mathrm{B}$. Akt is activated downstream of PI3K. ${ }^{44}$ Many bacterial effector proteins trigger the Akt pathway to manipulate host cell function leading to increased adherence and invasion and inducing cytoskeletal rearrangements. ${ }^{45}$ However, in our studies, phosphorylation of Akt was not detected in response to EHEC infection, supporting previous findings that EHEC infection inhibits activation of the Akt/NF $\kappa \mathrm{B}$ signaling cascade. ${ }^{46}$ Recruitment of PI3K to lipid rafts likely stimulates alternate signaling pathways, such as small GTP-binding proteins, leading to pedestal formation in the apical cytoplasm beneath intimately adherent AE organisms. ${ }^{47}$

The characteristic AE lesions seen in eukaryotic cells after noninvasive EHEC O157:H7 infection involves the presence of intact specialized lipid microdomains. ${ }^{20}$ We show, for the first time, using antibody against two closely related PI3K p85 subunits $(\alpha \text { and } \beta)^{48}$ that EHEC hijacks epithelial cell membrane lipid microdomains to recruit the second messenger PI3K. Such a recruitment was not the result of external bacterial surface structures, because PI3K recruitment to lipid rafts was only observed when cells were infected with live microorganism and not when using heat-killed bacteria.

Recruitment of PI3K to lipid rafts was observed when epithelial cell monolayers were infected with EHEC strain 
CVD-451, a type III secretion mutant; indicating that PI3K recruitment to lipid rafts is mediated by a nontype III secretion system bacterial effector. ${ }^{49}$ This recruitment may be induced by secreted bacterial effectors localized in detergent-resistant microdomains with the ability to recruit SH2/3 ligands, leading to pedestal formation. This has been shown previously, for example, when using Tir derived from an enteropathogenic E. coli strain. ${ }^{50}$

Cells infected with chloramphenicol-treated bacteria to block prokaryotic protein synthesis ${ }^{18}$ reduced the recruitment of PI3K to lipid rafts during the infectious process. This finding indicates that new bacterial protein(s) secreted
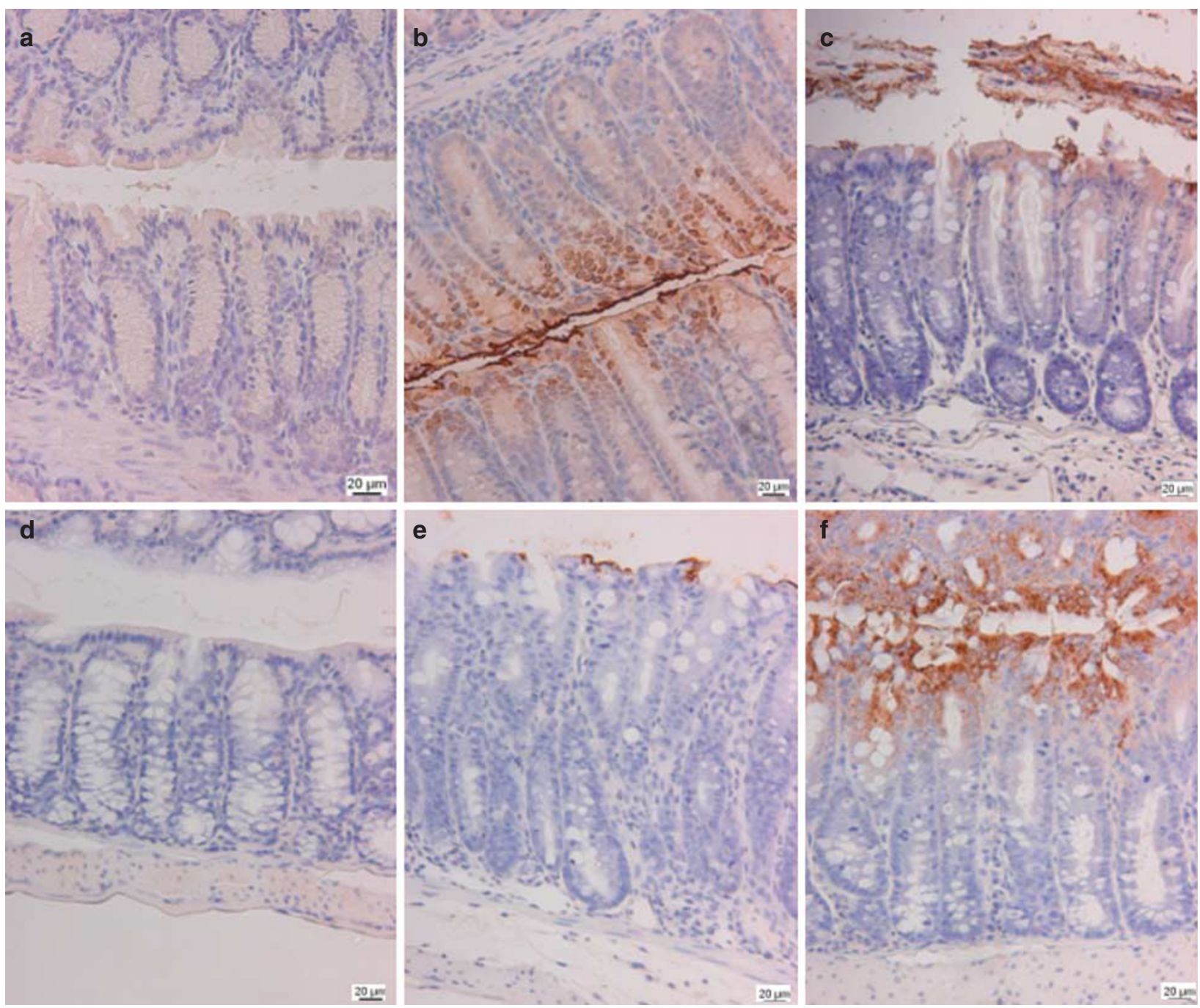

Figure 4 Citrobacter rodentium colonization is delayed in the colonic mucosa of NPC ${ }^{-1-}$ mice. Immunohistochemistry of colonic mucosa stained with antibody against $C$. rodentium. Uninfected wild-type BALB/C (a). Wild-type BALB/c mice infected for 6 days show a thick band of $C$. rodentium adherent along the apical aspect of the luminal mucosa (b). Wild-type BALB/c mice infected for 12 days showed $C$. rodentium staining of luminal contents and few adherent bacteria (c). Uninfected NPC ${ }^{-1-}$ mouse colon (d). C. rodentium-infected NPC ${ }^{-1-}$ colonic sections obtained 6 days after infectious challenge show a few patches of adherent bacteria (e). NPC ${ }^{-1-}$ tissues obtained from colons 12 days after infection showed C. rodentium binding to mucosal surfaces of colonocytes (f). Approximate original magnifications for each photomicrograph, $\times 200$.

Figure 5 Attaching-effacing (AE) lesions induced by Citrobacter rodentium infection are delayed in NPC ${ }^{-1-}$ mice. Transmission electron photomicrographs of distal colonic mucosa of uninfected BALB/C columnar epithelium with an intact brush border (a). Higher magnification of an AE lesion-producing C. rodentium bacterium (cr) on a BALB/c colonocyte 6 days after inoculation (b). The AE lesion shows characteristic effacement of the brush border microvilli at the site of intimate bacterial adherence and an F-actin-enriched pedestal underlying the adherent bacterium. BALB/c mice colonic tissue obtained 12 days after infectious challenge was devoid of AE lesions (c). Uninfected NPC mouse tissue (d). NPC ${ }^{-1-}$ mouse colon collected 6 days after C. rodentium orogastric inoculation lacked AE lesions (e). Bound C. rodentium (cr) to an NPC ${ }^{-1-}$ colonocyte 12 days after challenge forms AE lesions (f). Bars $=2 \mu \mathrm{m}$. 
a

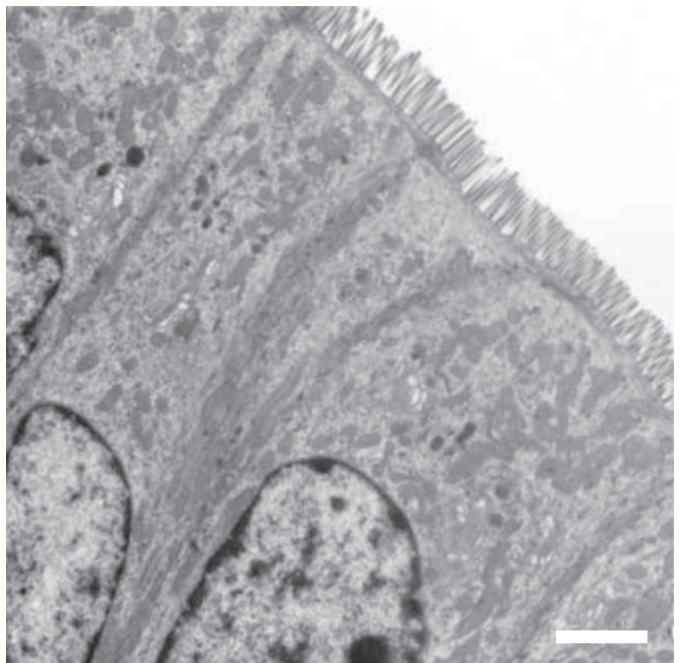

b

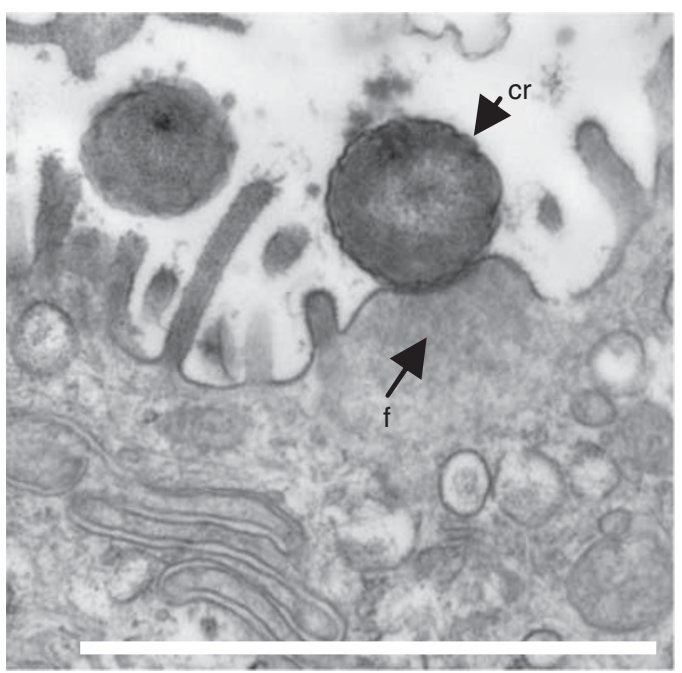

C

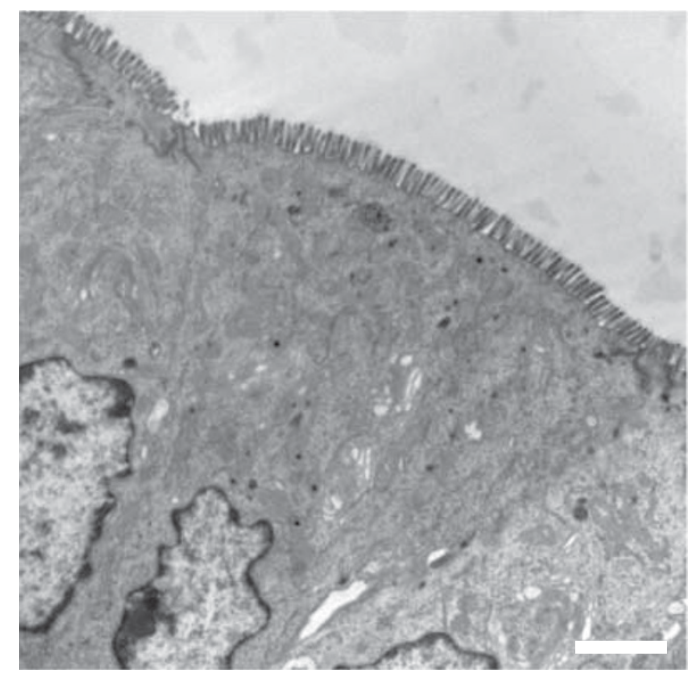

d

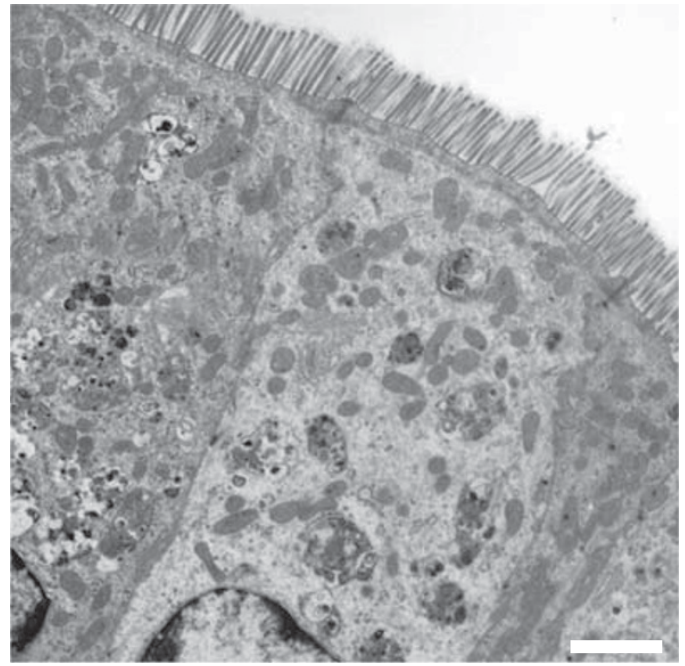

e

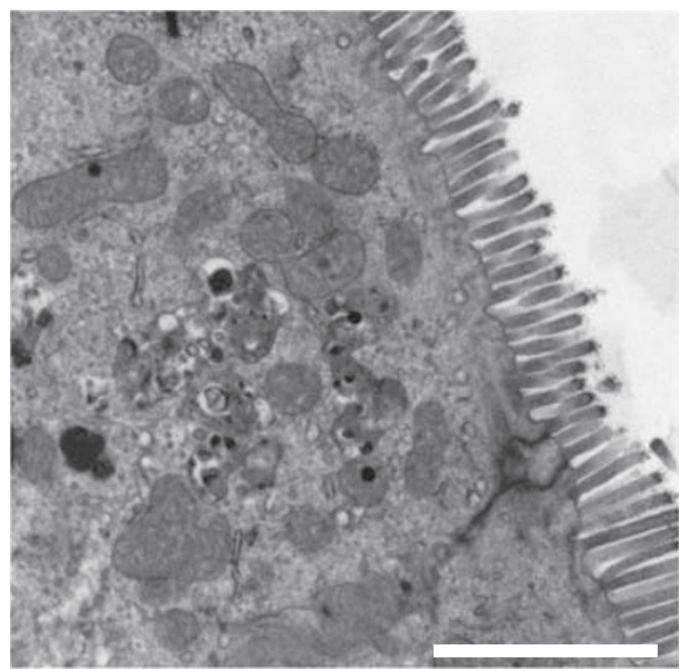

f





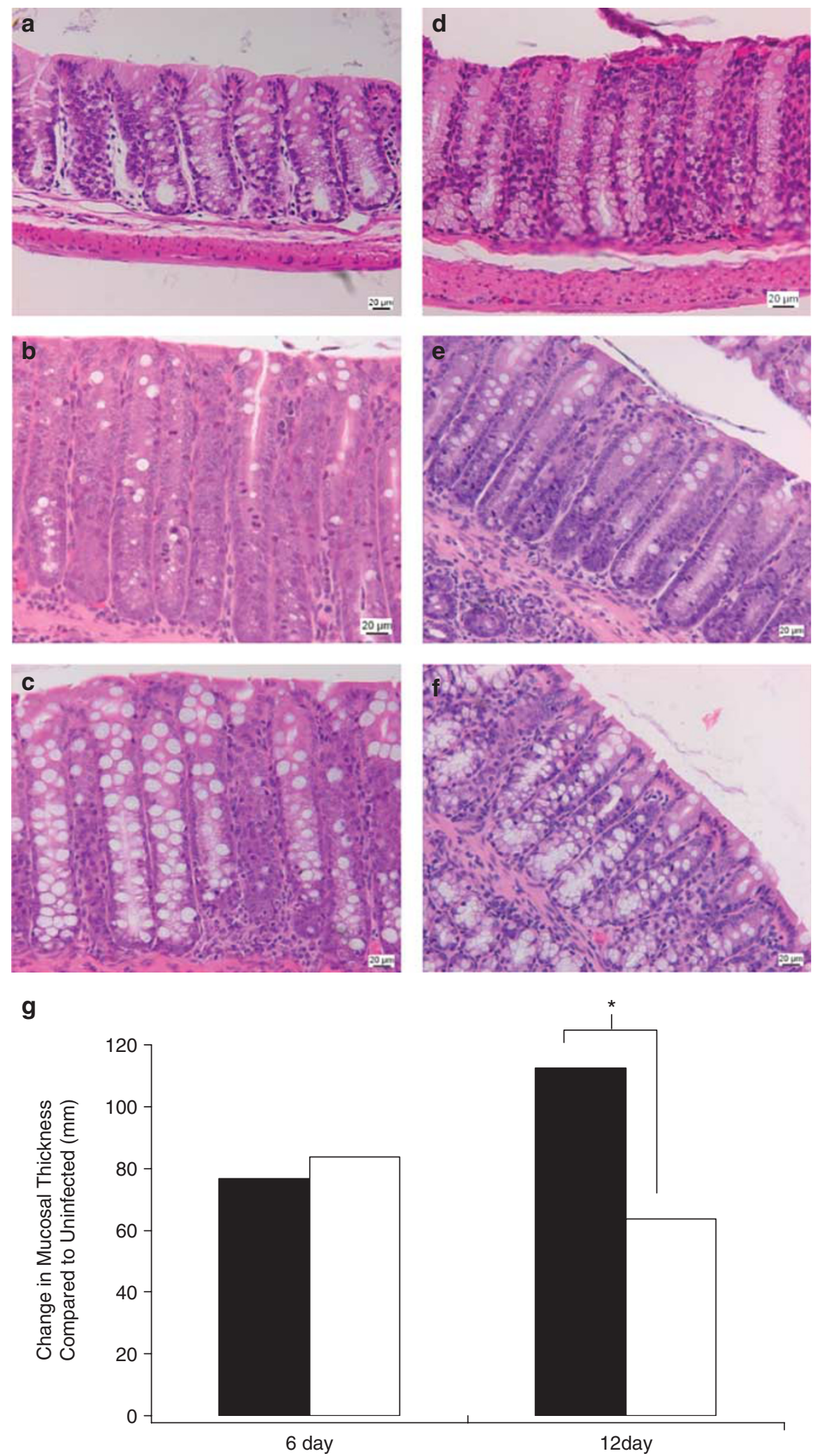

Figure 6 Citrobacter rodentium-induced epithelial cell hyperplasia is reduced in NPC ${ }^{-1-}$ mice. Photomicrographs of representative colonic sections showing increases in crypt length in response to C. rodentium infection. Uninfected BALB/C (a), 6-day-infected BALB/C (b), 12-day-infected BALB/C (c), Uninfected


uninfected baseline values were quantified $(\mathbf{g})$. A difference in the change in crypt length was observed at 12 days after infection $(64 \pm 8.251 \mu \mathrm{m} v \mathrm{~s}$ $\left.112 \pm 2.958 \mu \mathrm{m} ;{ }^{*} P<0.05\right)$, but not at 6 days after infection. $\mathrm{BALB} / \mathrm{c}=$ black bars, NPC ${ }^{-l-}=$ white bars. 

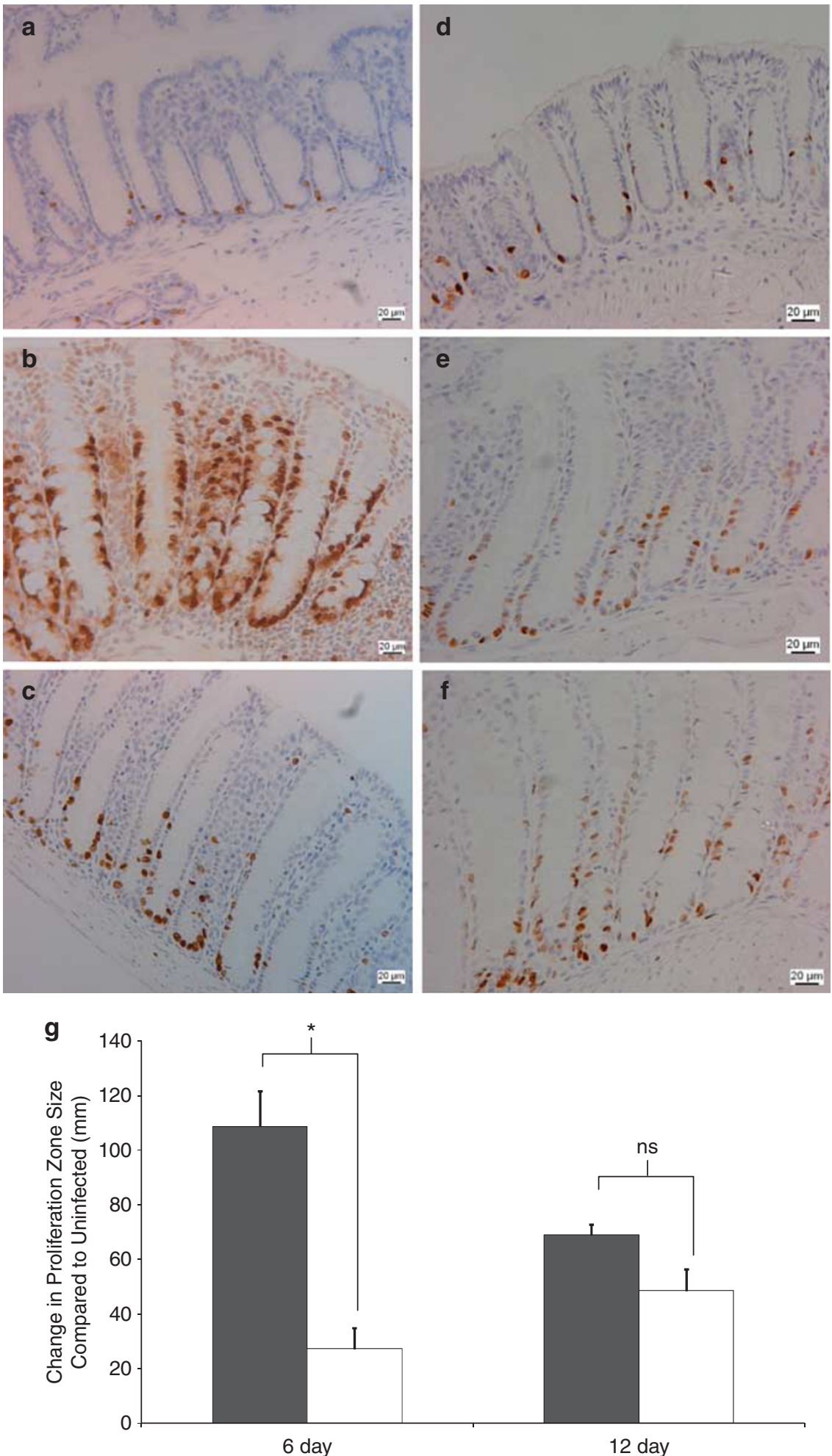

Figure 7 Colonocyte proliferation is reduced in $\mathrm{NPC}^{-1-}$ mice infected with Citrobacter rodentium. Photomicrographs of colonic sections showing proliferating colonocytes through incorporation of BrdU during mitosis. Uninfected BALB/c crypts show few BrdU-positive dividing colonocytes (a). Large

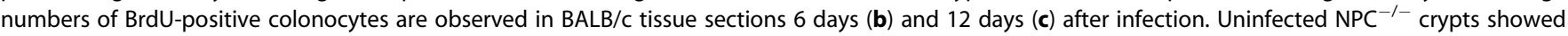
few proliferating cells (d), and NPC ${ }^{-1-}$ colonic sections both 6 days (e) and 12 days (f) after infection had just a moderate increase in the number of BrdUpositive cells. Approximate original magnification for each photomicrograph, $\times 200$. The size of the zone of proliferation was quantified and expressed as the change in zone size over the uninfected baseline $(\mathbf{g})$. Proliferation was maximal in BALB/c mice 6 days after infection $(71 \pm 26.3 \mathrm{pg} / \mathrm{ml} \mathrm{vs} 17.6 \pm 17.6 \mathrm{pg} /$ $\left.\mathrm{ml},{ }^{*} P<0.001\right)$. No differences were observed between $\mathrm{BALB} / \mathrm{c}$ and $\mathrm{NPC}^{-1-}$ mice 12 days after infection. $\mathrm{BALB} / \mathrm{c}=$ black bars, $\mathrm{NPC}^{-1-}=\mathrm{white}$ bars. 

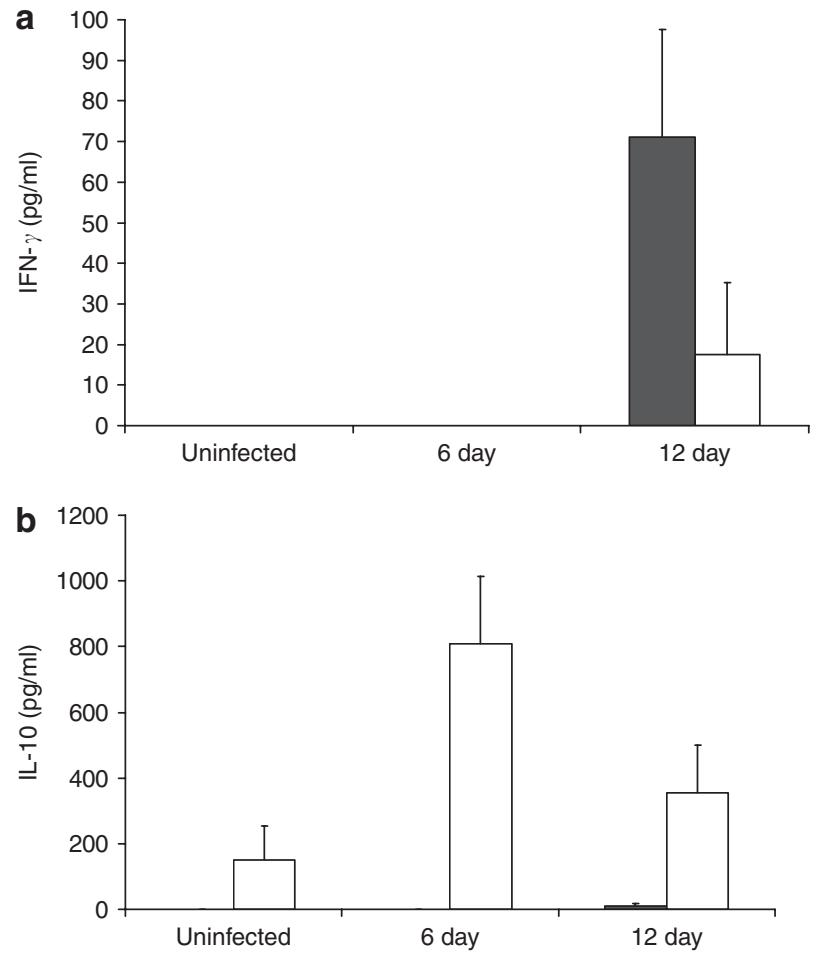

Figure 8 Altered cytokine profiles in NPC ${ }^{-1-}$ mice infected with Citrobacter rodentium. Cytokine profiles of splenocytes isolated from uninfected and $C$. rodentium-challenged BALB/C (black bars) and NPC ${ }^{-1-}$ (white bars) mice incubated with $C$. rodentium sonicates. IFN- $\gamma$ secretion 12 days after infection was reduced in $\mathrm{NPC}^{-1-}$ mice $(P<0.05)(\mathbf{a})$. Antiinflammatory cytokine IL-10 secretion was increased at both $6(P<0.001)$ and 12 days $(P<0.05)$ after $C$. rodentium infection of NPC ${ }^{-1-}$ mice $(\mathbf{b})$.

into the culture medium triggers the recruitment of PI3K to cholesterol-enriched microdomains in the host cell plasma membrane. However, secreted bacterial factors alone (using conditioned medium collected from host-bacteria cocultures) did not induce the recruitment of PI3K to lipid rafts. Therefore, bacterial attachment to the cell monolayer is required. Such contact-dependent effects have been described previously. ${ }^{40}$

Although production of Shiga toxins is reported to promote bacterial colonization in the human intestine, ${ }^{51}$ the ability of EHEC O157:H7 to elaborate Shiga toxins does not have a role in recruiting PI3K to lipid rafts. ${ }^{52}$ The reduction in EHEC-induced PI3K recruitment to lipid rafts in the presence of a specific pharmacological inhibitor against PI3K suggests that an activated protein was recruited. Such a recruitment is most likely the first step that leads to epithelial barrier disruption and reorganization of the host cell cytoskeleton.

Previous studies have shown that the presence of cholesterol-enriched plasma membrane microdomains in vitro is required for adherence and pedestal formation by $\mathrm{AE}$ E. coli. ${ }^{11,20}$ When lipid rafts are disrupted with the cholesterol-sequestering reagent, $\mathrm{M} \beta \mathrm{CD}$, EHEC no longer induces the translocation of PI3K to lipid rafts. The presence of caveolin-1 in low-density fraction even after $\mathrm{M} \beta \mathrm{CD}$ treatment is likely because of an uneven distribution of caveolin-1 in caveolae present on the basolateral aspect of the plasma membrane and in membranes surrounding intracellular organelles. ${ }^{53}$ An alternative explanation is that cholesterol is more readily removed from nonmicrodomain regions than from the liquid-ordered phase in which it is more tightly packed and less easily extracted by agents such as $\mathrm{M} \beta \mathrm{CD} .^{54}$

The interaction of microbial pathogens with host cell membrane cholesterol and lipid rafts has become a major theme of interest in disease pathogenesis. ${ }^{55,56}$ Previous in vitro studies show that multiple bacteria, including Salmonella, ${ }^{57}$ Shigella, ${ }^{58}$ Brucella, ${ }^{59}$ and E. coli, ${ }^{11,20,60}$ interact with these cholesterol-enriched microdomains. However, the molecular mechanisms underlying these interactions are still largely undefined. Direct interactions of bacterial proteins with host lipid rafts have been described. For example, type III secretion system bacterial effectors from Salmonella $\mathrm{PipB}^{61}$ and EPEC $\operatorname{Tir}^{11}$ are targeted to lipid rafts, whereas Salmonella SipB and Shigella IpaB are cholesterol-binding proteins. $^{62}$

We showed previously that depletion of cellular cholesterol decreases intimate attachment of $\mathrm{AE} E$. coli. ${ }^{20} \mathrm{AE}$ lesions were restored when cells are allowed to recover cholesterol. ${ }^{20}$ These findings were confirmed using primary fibroblasts harboring a defect in the Niemann-Pick C 1 (NPC1) gene. ${ }^{20}$ NiemannPick type $\mathrm{C}$ disease is a cholesterol storage disorder resulting in neurodegeneration. ${ }^{63}$ Mutations in $n p c 1$ and $n p c 2$ result in aberrant lipid transport, ${ }^{64,65}$ which results in decreased lipid rafts and lipid raft-associated markers on the plasma membrane of affected cells. ${ }^{66}$ Taken together, these findings suggest that lipid rafts are required for $\mathrm{AE}$ lesion formation in response to EHEC O157:H7 and C. rodentium infection in vitro. Using a series of pharmacological inhibitors, we previously identified that host enzymes, including phospholipase C- $\gamma$ (PLC- $\gamma)$ and PI3K), are involved in the signal transduction cascades that lead to cytoskeletal rearrangements. ${ }^{21}$

In this study, we describe the importance of cholesterol during host-pathogen interactions of the mouse pathogen C. rodentium in vivo. To our knowledge, this is the first in vivo study confirming an interaction between host cholesterol-enriched microdomains and an $\mathrm{AE}$ noninvasive enteric bacterial pathogen. Although $C$. rodentium infection of wild-type $\mathrm{BALB} / \mathrm{c}$ mice resulted in $\mathrm{AE}$ lesion formation maximally at 6 days after infection, $C$. rodentium-induced lesions in $\mathrm{NPC}^{-1-}$ mice were found later during the infection period, at 12 days. This difference is likely because of the inability of $C$. rodentium to bind and colonize $\mathrm{NPC}^{-/-} \mathrm{co}^{-}$ lonic mucosa, despite similar shedding patterns in $\mathrm{BALB} / \mathrm{c}$ and $\mathrm{NPC}^{-1-}$ mice. Maximum colonization occurred on days 6 and 10 after infection in wild-type mice and was decreased by postinfection day 15 with resolution of disease. Such a recovery was not observed in NPC mice infected with C. rodentium. Colonization data suggest that there could be a 
secondary, alternative binding mechanism for C. rodentium to attach to the colonic mucosa. Partitioning of PI3K into cholesterol-rich microdomains is necessary, but not sufficient, to induce $\mathrm{AE}$ lesions.

Adherence of $C$. rodentium to colonocytes correlated with maximal responses in cellular proliferation. The timedependent binding could delay $C$. rodentium pathogenesis in the $\mathrm{NPC}^{-1-}$ mouse, resulting in a less-severe colonic epithelial cell hyperplasia response, compared with infection in wild-type mice. Colonization and binding of $C$. rodentium to mucosal surfaces require multiple factors. Initial adhesion of the bacterium to host cells is believed to be accomplished by the colonization factor Citrobacter (CFC) type IV pilus. ${ }^{67}$ After initial adherence, AE pathogens secrete Tir directly into the host plasma membrane. Tir mutants are unable to colonize wild-type mice and do not cause disease. ${ }^{68}$ The LEE pathogenicity island locus encodes Tir, an effector protein that has been isolated from lipid rafts. ${ }^{11}$ Furthermore, the type III secretion system that delivers Tir to the host cell is regulated by lipid rafts, ${ }^{69}$ and utilizes these cholesterol-rich microdomains as targets for pore formation, ${ }^{62}$ thereby allowing for a direct link between the bacterium and host cells. During the normal course of infection, C. rodentium colonizes the colon within the first 2-3 days after infection, ${ }^{67}$ and is recovered in fecal samples for no more than a few weeks. $^{70}$ Noncolonizing mutants, by contrast, are cleared within days of inoculation. ${ }^{68}$ Preventing either the initial attachment of $C$. rodentium to host cells or Tir translocation would serve to inhibit the colonization that was observed in $\mathrm{NPC}^{-1-}$-infected mice.

The observation that maximal mitotic responses (incorporation of BrdU) occurred during times of maximal binding of bacteria to colonic surfaces confirms the belief that the hyperplastic response is contact dependent. Thus, reduced adhesion of $C$. rodentium to $\mathrm{NPC}^{-1-}$ colonic mucosa may similarly abrogate the epithelial cell hyperplasic response. Current evidence indicates that colonic hyperplasia is dependent on the non-LEE-encoded effector A (NleA, also known as EspI), ${ }^{71}$ as $C$. rodentium strains harboring deletions in nleA do not result in colonic epithelial cell hyperplasia. ${ }^{72}$

Reductions in lipid-raft microdomains are also likely to affect type III secretion. Thus, decreased transfer of NleA in $\mathrm{NPC}^{-1-}$ mice could well have a role in reducing the proliferative responses in colonocytes. On the other hand, C. rodentium infection also results in the production of serine proteases, which activate the proteinase-activated receptor 2 (PAR2) ${ }^{73}$ Infected mice treated with a serine proteinase inhibitor and $\mathrm{PAR}^{-1-}$ mice show decreased hyperplastic changes in colonic mucosa. ${ }^{23}$ Whether PAR2 activation is deficient in $\mathrm{NPC}^{-1-}$ cells is not known, but PAR2 signaling is mediated by G-proteins, which are known to associate with lipid-raft microdomains. ${ }^{13}$

Another important factor affecting the development of C. rodentium-induced colonic epithelial cell hyperplasia is the host immune system. ${ }^{74}$ C. rodentium elicits a distinct proinflammatory cytokine response characterized by high levels of Th1 cytokines, including IFN- $\gamma$ and IL-12. ${ }^{36}$ In this study, there was a decrease in proinflammatory cytokine responses in $\mathrm{NPC}^{-1-}$ mice challenged with $C$. rodentium, as well as marked differences in the secreted $\mathrm{T}_{\text {regulatory }}$ cytokine profile. IL-10 is an anti-inflammatory cytokine that acts to counterbalance proinflammatory signals. ${ }^{75,76}$ Other studies have noted varying effects, with increases in both $\mathrm{T}_{\text {regulatory }}$ and Th2 cytokines in response to $C$. rodentium infection. Johnson-Henry et al ${ }^{27}$ observed that mice pretreated with probiotics had elevated IL-10 secretion from splenocytes and ameliorated C. rodentium disease pathogenesis. By contrast, helminth infection, which elevates Th2 cytokine responses, prevents colitis in noninfectious animal models, ${ }^{77,78}$ but results in an increased severity of disease in response to C. rodentium infection. ${ }^{37} \mathrm{~A}$ major difference between these outcomes is the ability of $C$. rodentium to bind to the mucosal surface.

Taken together, these complementary in vitro and in vivo studies of host epithelial cell responses to noninvasive, $\mathrm{AE}$ pathogens show the importance of cholesterol-enriched microdomains as signal transduction platforms that mediate signaling between the infecting organism and the cytosol of the host epithelial cell.

\section{ACKNOWLEDGEMENTS}

This work was supported by operating grants from the Canadian Institute for Health Research (CIHR). GS-T was the recipient of a CIHR Canada Graduate Scholarship-Master's Award, CIHR Frederick Banting, and Charles Best Canada Graduate Scholarships_-Doctoral Award and research training funding support provided by the SickKids Foundation Graduate

Scholarships at the University of Toronto. In vivo studies were conducted by Jason D Riff, who was supported through a studentship by the Ontario Student Opportunity Trust Fund-Hospital for Sick Children Foundation Student Scholarship Program, and a University of Toronto Fellowship. PMS is the recipient of a Canada Research Chair in Gastrointestinal Disease.

\section{DISCLOSURE/CONFLICT OF INTEREST}

The authors declare no conflict of interest.

1. Kaper JB, Nataro JP, Mobley HL. Pathogenic Escherichia coli. Nat Rev Microbiol 2004;2:123-140.

2. Jandu N, Shen S, Wickham ME, et al. Multiple seropathotypes of verotoxin-producing Escherichia coli (VTEC) disrupt interferon-gammainduced tyrosine phosphorylation of signal transducer and activator of transcription (Stat)-1. Microb Pathog 2007;42:62-71.

3. Cooley M, Carychao D, Crawford-Miksza L, et al. Incidence and tracking of Escherichia coli $0157: \mathrm{H7}$ in a major produce production region in California. PLoS ONE 2007;2:e1159.

4. Rendon MA, Saldana Z, Erdem AL, et al. Commensal and pathogenic Escherichia coli use a common pilus adherence factor for epithelial cell colonization. Proc Natl Acad Sci USA 2007;104:10637-10642.

5. Nutikka A, Lingwood C. Generation of receptor-active, globotriaosyl ceramide/cholesterol lipid 'rafts' in vitro: a new assay to define factors affecting glycosphingolipid receptor activity. Glycoconj J 2004;20:33-38.

6. Gobert $A P$, Vareille $M$, Glasser $A L$, et al. Shiga toxin produced by enterohemorrhagic Escherichia coli inhibits PI3K/NF-kappaB signaling pathway in globotriaosylceramide-3-negative human intestinal epithelial cells. J Immunol 2007;178:8168-8174.

7. Gyles CL. Shiga toxin-producing Escherichia coli: an overview. J Anim Sci 2007;85(13 Suppl):E45-E62. 
8. Welinder-Olsson C, Kaijser B. Enterohemorrhagic Escherichia coli (EHEC). Scand J Infect Dis 2005;37:405-416.

9. Campellone KG, Robbins D, Leong JM. EspFU is a translocated EHEC effector that interacts with Tir and N-WASP and promotes Nckindependent actin assembly. Dev Cell 2004;7:217-228.

10. Mundy R, MacDonald TT, Dougan G, et al. Citrobacter rodentium of mice and man. Cell Microbiol 2005;7:1697-1706.

11. Allen-Vercoe $E$, Waddell $B$, Livingstone $S$, et al. Enteropathogenic Escherichia coli Tir translocation and pedestal formation requires membrane cholesterol in the absence of bundle-forming pili. Cell Microbiol 2006;8:613-624.

12. Zobiack N, Rescher U, Laarmann S, et al. Cell-surface attachment of pedestal-forming enteropathogenic $E$. coli induces a clustering of raft components and a recruitment of annexin 2. J Cell Sci 2002;115 (Part 1):91-98.

13. Simons K, Toomre D. Lipid rafts and signal transduction. Nat Rev Mol Cell Biol 2000;1:31-39.

14. Brown DA, London E. Functions of lipid rafts in biological membranes. Annu Rev Cell Dev Biol 1998;14:111-136.

15. Fielding $\mathrm{CJ}$, Fielding PE. Membrane cholesterol and the regulation of signal transduction. Biochem Soc Trans 2004;32(Part 1):65-69.

16. Laude AJ, Prior IA. Plasma membrane microdomains: organization, function and trafficking. Mol Membr Biol 2004;21:193-205.

17. Ceponis PJ, McKay DM, Ching JC, et al. Enterohemorrhagic Escherichia coli 0157:H7 disrupts Stat1-mediated gamma interferon signal transduction in epithelial cells. Infect Immun 2003;71:1396-1404.

18. Jandu N, Ceponis PJ, Kato $\mathrm{S}$, et al. Conditioned medium from enterohemorrhagic Escherichia coli-infected T84 cells inhibits signal transducer and activator of transcription 1 activation by gamma interferon. Infect Immun 2006;74:1809-1818.

19. Kilsdonk EP, Yancey PG, Stoudt GW, et al. Cellular cholesterol efflux mediated by cyclodextrins. J Biol Chem 1995;270:17250-17256.

20. Riff JD, Callahan JW, Sherman PM. Cholesterol-enriched membrane microdomains are required for inducing host cell cytoskeleton rearrangements in response to attaching-effacing Escherichia coli. Infect Immun 2005;73:7113-7125.

21. Johnson-Henry K, Wallace JL, Basappa NS, et al. Inhibition of attaching and effacing lesion formation following enteropathogenic Escherichia coli and Shiga toxin-producing $E$. coli infection. Infect Immun 2001:69:7152-7158.

22. Schraw W, Li Y, McClain MS, et al. Association of Helicobacter pylori vacuolating toxin (VacA) with lipid rafts. J Biol Chem 2002;277: 34642-34650.

23. Song KS, Li S, Okamoto T, et al. Co-purification and direct interaction of Ras with caveolin, an integral membrane protein of caveolae microdomains. Detergent-free purification of caveolae microdomains. J Biol Chem 1996;271:9690-9697.

24. Macdonald JL, Pike LJ. A simplified method for the preparation of detergent-free lipid rafts. J Lipid Res 2005;46:1061-1067.

25. Hatano T, Kubo S, Imai S, et al. Leucine-rich repeat kinase 2 associates with lipid rafts. Hum Mol Genet 2007;16:678-690.

26. Dennis A, Kudo T, Kruidenier L, et al. The p50 subunit of NF-kappaB is critical for in vivo clearance of the noninvasive enteric pathogen Citrobacter rodentium. Infect Immun 2008;76:4978-4988.

27. Johnson-Henry KC, Nadjafi M, Avitzur Y, et al. Amelioration of the effects of Citrobacter rodentium infection in mice by pretreatment with probiotics. J Infect Dis 2005;191:2106-2117.

28. Mogilner JG, Srugo I, Lurie M, et al. Effect of probiotics on intestinal regrowth and bacterial translocation after massive small bowel resection in a rat. J Pediatr Surg 2007;42:1365-1371.

29. Kubo M, Li TS, Suzuki R, et al. Hypoxic preconditioning increases survival and angiogenic potency of peripheral blood mononuclear cells via oxidative stress resistance. Am J Physiol Heart Circ Physiol 2008;294:H590-H595.

30. Jones NL, Day AS, Jennings $\mathrm{H}$, et al. Enhanced disease severity in Helicobacter pylori-infected mice deficient in Fas signaling. Infect Immun 2002;70:2591-2597.

31. Bewick V, Cheek L, Ball J. Statistics review 9: one-way analysis of variance. Crit Care 2004;8:130-136.

32. Cole LE, Shirey KA, Barry E, et al. Toll-like receptor 2-mediated signaling requirements for Francisella tularensis live vaccine strain infection of murine macrophages. Infect Immun 2007;75:4127-4137.
33. Shen $\mathrm{S}$, Mascarenhas $\mathrm{M}$, Rahn $\mathrm{K}$, et al. Evidence for a hybrid genomic island in verocytotoxin-producing Escherichia coli CL3 (serotype O113:H21) containing segments of EDL933 (serotype O157:H7) O islands 122 and 48. Infect Immun 2004;72:1496-1503.

34. Cantley LC. The phosphoinositide 3-kinase pathway. Science 2002;296:1655-1657.

35. Borenshtein D, McBee ME, Schauer DB. Utility of the Citrobacter rodentium infection model in laboratory mice. Curr Opin Gastroenterol 2008:24:32-37.

36. Higgins LM, Frankel G, Douce G, et al. Citrobacter rodentium infection in mice elicits a mucosal Th1 cytokine response and lesions similar to those in murine inflammatory bowel disease. Infect Immun 1999;67:3031-3039.

37. Chen CC, Louie S, McCormick B, et al. Concurrent infection with an intestinal helminth parasite impairs host resistance to enteric Citrobacter rodentium and enhances Citrobacter-induced colitis in mice. Infect Immun 2005;73:5468-5481.

38. Ismaili A, Philpott DJ, Dytoc MT, et al. Signal transduction responses following adhesion of verocytotoxin-producing Escherichia coli. Infect Immun 1995;63:3316-3326.

39. Shaner NC, Sanger JW, Sanger JM. Actin and alpha-actinin dynamics in the adhesion and motility of EPEC and EHEC on host cells. Cell Motil Cytoskeleton 2005;60:104-120.

40. Philpott DJ, McKay DM, Mak W, et al. Signal transduction pathways involved in enterohemorrhagic Escherichia coli-induced alterations in T84 epithelial permeability. Infect Immun 1998;66:1680-1687.

41. Pizarro-Cerda J, Cossart P. Bacterial adhesion and entry into host cells. Cell 2006:124:715-727.

42. Kierbel A, Gassama-Diagne A, Rocha C, et al. Pseudomonas aeruginosa exploits a PIP3-dependent pathway to transform apical into basolateral membrane. J Cell Biol 2007;177:21-27.

43. Kierbel A, Gassama-Diagne A, Mostov K, et al. The phosphoinositol-3kinase-protein kinase B/Akt pathway is critical for Pseudomonas aeruginosa strain PAK internalization. Mol Biol Cell 2005;16:2577-2585.

44. Wiles TJ, Dhakal BK, Eto DS, et al. Inactivation of host Akt/protein kinase B signaling by bacterial pore-forming toxins. Mol Biol Cell 2008;19:1427-1438.

45. Edwards JL, Apicella MA. Neisseria gonorrhoeae PLD directly interacts with Akt kinase upon infection of primary, human, cervical epithelial cells. Cell Microbiol 2006;8:1253-1271.

46. Bosse T, Ehinger J, Czuchra A, et al. Cdc42 and phosphoinositide 3-kinase drive Rac-mediated actin polymerization downstream of c-Met in distinct and common pathways. Mol Cell Biol 2007;27: 6615-6628.

47. Takenouchi $\mathrm{H}$, Kiyokawa N, Taguchi T, et al. Shiga toxin binding to globotriaosyl ceramide induces intracellular signals that mediate cytoskeleton remodeling in human renal carcinoma-derived cells. J Cell Sci 2004;117(Part 17):3911-3922.

48. Tang CH, Lu DY, Yang RS, et al. Leptin-induced IL-6 production is mediated by leptin receptor, insulin receptor substrate-1, phosphatidylinositol 3-kinase, Akt, NF-kappaB, and p300 pathway in microglia. J Immunol 2007;179:1292-1302.

49. Guttman JA, Li Y, Wickham ME, et al. Attaching and effacing pathogen-induced tight junction disruption in vivo. Cell Microbiol 2006;8:634-645.

50. Sason H, Milgrom M, Weiss AM, et al. Enteropathogenic Escherichia coli subverts phosphatidylinositol 4,5-bisphosphate and phosphatidylinositol 3,4,5-trisphosphate upon epithelial cell infection. Mol Biol Cell 2009;20:544-555.

51. Robinson CM, Sinclair JF, Smith MJ, et al. Shiga toxin of enterohemorrhagic Escherichia coli type 0157:H7 promotes intestinal colonization. Proc Natl Acad Sci USA 2006;103:9667-9672.

52. Proulx F, Seidman EG, Karpman D. Pathogenesis of Shiga toxinassociated hemolytic uremic syndrome. Pediatr Res 2001;50:163-171.

53. Absi M, Burnham MP, Weston AH, et al. Effects of methyl betacyclodextrin on EDHF responses in pig and rat arteries; association between SK(Ca) channels and caveolin-rich domains. $\mathrm{Br} J$ Pharmacol 2007;151:332-340

54. Marbeuf-Gueye C, Stierle V, Sudwan P, et al. Perturbation of membrane microdomains in GLC4 multidrug-resistant lung cancer cellsmodification of ABCC1 (MRP1) localization and functionality. FEBS J 2007;274:1470-1480. 
55. Goluszko P, Nowicki B. Membrane cholesterol: a crucial molecule affecting interactions of microbial pathogens with mammalian cells. Infect Immun 2005;73:7791-7796.

56. Lafont F, van der Goot FG. Bacterial invasion via lipid rafts. Cell Microbiol 2005;7:613-620.

57. Catron DM, Sylvester MD, Lange $Y$, et al. The salmonella-containing vacuole is a major site of intracellular cholesterol accumulation and recruits the GPI-anchored protein CD55. Cell Microbiol 2002;4:315-328.

58. Lafont F, Tran Van Nhieu G, Hanada K, et al. Initial steps of Shigella infection depend on the cholesterol/sphingolipid raft-mediated CD44IpaB interaction. EMBO J 2002;21:4449-4457.

59. Watarai M, Makino S, Michikawa M, et al. Macrophage plasma membrane cholesterol contributes to Brucella abortus infection of mice. Infect Immun 2002;70:4818-4825.

60. Kansau I, Berger C, Hospital M, et al. Zipper-like internalization of Dr-positive Escherichia coli by epithelial cells is preceded by an adhesin-induced mobilization of raft-associated molecules in the initial step of adhesion. Infect Immun 2004;72:3733-3742.

61. Knodler LA, Vallance BA, Hensel $M$, et al. Salmonella type III effectors PipB and PipB2 are targeted to detergent-resistant microdomains on internal host cell membranes. Mol Microbiol 2003;49:685-704.

62. Hayward RD, Cain RJ, McGhie EJ, et al. Cholesterol binding by the bacterial type III translocon is essential for virulence effector delivery into mammalian cells. Mol Microbiol 2005;56:590-603.

63. Chang TY, Reid PC, Sugii S, et al. Niemann-Pick type $C$ disease and intracellular cholesterol trafficking. J Biol Chem 2005;280:20917-20920.

64. Liscum L, Sturley SL. Intracellular trafficking of Niemann-Pick C proteins 1 and 2: obligate components of subcellular lipid transport. Biochim Biophys Acta 2004;1685:22-27.

65. Mukherjee S, Maxfield FR. Lipid and cholesterol trafficking in NPC Biochim Biophys Acta 2004;1685:28-37.

66. Garver WS, Krishnan K, Gallagos JR, et al. Niemann-Pick C1 protein regulates cholesterol transport to the trans-Golgi network and plasma membrane caveolae. J Lipid Res 2002;43:579-589.
67. Mundy R, Pickard D, Wilson RK, et al. Identification of a novel type IV pilus gene cluster required for gastrointestinal colonization of Citrobacter rodentium. Mol Microbiol 2003;48:795-809.

68. Schauer DB, Falkow S. The eae gene of Citrobacter freundii biotype 4280 is necessary for colonization in transmissible murine colonic hyperplasia. Infect Immun 1993;61:4654-4661.

69. van der Goot FG, Tran van Nhieu G, Allaoui A, et al. Rafts can trigger contact-mediated secretion of bacterial effectors via a lipid-based mechanism. J Biol Chem 2004;279:47792-47798.

70. Wiles S, Clare S, Harker J, et al. Organ specificity, colonization and clearance dynamics in vivo following oral challenges with the murine pathogen Citrobacter rodentium. Cell Microbiol 2004;6:963-972.

71. Gruenheid S, Sekirov I, Thomas NA, et al. Identification and characterization of NleA, a non-LEE-encoded type III translocated virulence factor of enterohaemorrhagic Escherichia coli O157:H7. Mol Microbiol 2004;51:1233-1249.

72. Mundy R, Petrovska L, Smollett K, et al. Identification of a novel Citrobacter rodentium type III secreted protein, Espl, and roles of this and other secreted proteins in infection. Infect Immun 2004;72:2288-2302.

73. Hansen KK, Sherman PM, Cellars L, et al. A major role for proteolytic activity and proteinase-activated receptor- 2 in the pathogenesis of infectious colitis. Proc Natl Acad Sci USA 2005;102:8363-8368.

74. Artis D, Potten CS, Else KJ, et al. Trichuris muris: host intestinal epithelial cell hyperproliferation during chronic infection is regulated by interferon-gamma. Exp Parasitol 1999;92:144-153.

75. O'Garra A, Vieira PL, Vieira P, et al. IL-10-producing and naturally occurring CD4+ Tregs: limiting collateral damage. J Clin Invest 2004;114:1372-1378.

76. Powrie F. Immune regulation in the intestine: a balancing act between effector and regulatory $\mathrm{T}$ cell responses. Ann N Y Acad Sci 2004;1029:132-141.

77. McKay DM. The beneficial helminth parasite? Parasitology 2006;132(Part 1):1-12

78. Reardon C, Sanchez A, Hogaboam CM, et al. Tapeworm infection reduces epithelial ion transport abnormalities in murine dextran sulfate sodium-induced colitis. Infect Immun 2001;69:4417-4423. 